\title{
Cash Holdings and Employee Welfare
}

\author{
Mohamed Ghaly, Viet Anh Dang, and Konstantinos Stathopoulos*
}

Manchester Business School, The University of Manchester, Booth Street West, Manchester, M15 6PB, UK.

\begin{abstract}
This paper examines the relation between employee welfare practices and corporate cash holdings. We find firms that are strongly committed to employee well-being, measured by ratings on employee relations, to hold more cash. The effect of employee welfare standards on cash holdings is stronger for firms in human-capital-intensive, competitive, and highlabor-mobility industries in which employees are more important to their businesses. These results are consistent with the predictions of the stakeholder theory. Overall, our paper provides novel evidence on the role human capital and employee relations play in a firm's cash management policy.
\end{abstract}

Keywords: Cash Holdings, Employee Welfare, Implicit Claims, Stakeholders, Human Capital.

JEL Classifications: G32, G34, M54.

E-mail Addresses: mohamed.ghaly@postgrad.mbs.ac.uk (M. Ghaly), Vietanh.Dang@mbs.ac.uk (V. A. Dang), k.stathopoulos@mbs.ac.uk (K. Stathopoulos).

* Corresponding author. Tel: +44(0) 161275 6863; fax: +44(0) 1612754023. 
"We should continue to innovate in our relationship with our employees and figure out the best things we can do for them [...] We've always been good at making sure we're treating employees flexibly. You treat people with respect, they tend to return the favor to the company." - Larry Page, Google CEO and cofounder, quoted in Fortune Magazine, 6/2/12.

\section{Introduction}

In today's competitive labor market, many firms are dealing with the challenges of recruiting and retaining talent by improving workplace standards and investing in employee benefits. Prior studies find that these employee-friendly practices have a favorable impact on firms' operational, financial, and stock price performance (Jiao, 2010; Faleye and Trahan, 2011; Edmans, 2011; Ertugrul, 2013). Accordingly, it is important to understand how a firm's commitment to employee well-being affects its financial policies. With the exception of a few studies that examine the potential influence of employee treatment on leverage (e.g., Verwijmeren and Derwall, 2010; Bae, Kang, and Wang, 2011), very little is known about the impact of employee welfare practices on financial policies, and in particular cash holdings. In this paper, we empirically examine how a firm's commitment to providing its employees with a quality workplace environment, as reflected by employee welfare ratings, affects its cash management policy.

The stakeholder theory suggests that a firm's financial policy is influenced by its relationship with non-financial stakeholders such as customers, suppliers, and employees (e.g., Titman, 1984; Cornell and Shapiro, 1987). In particular, Cornell and Shapiro (1987) argue that a firm should adopt a conservative financial policy to reassure its stakeholders that it can honor implicit claims, such as its promises to its employees about working conditions, employee benefits, career progression, job security, and retirement plans. Unlike explicit contractual claims (e.g., wages), which are legally binding and senior to the claims of bondholders and stockholders, implicit agreements between a firm and its stakeholders are 
generally non-contractual and have weak legal standing. From a valuation perspective, the payouts on these implicit claims are uncertain, suggesting that their value is highly sensitive to the firm's financial health and its reputation for fulfilling them.

We argue that there is a positive relation between employee-friendly practices and cash holdings. We base our argument on the stakeholder theory prediction that firms have incentives to make their implied promises to employees credible by maintaining substantial financial resources (Cornell and Shapiro, 1987). There are two potential reasons why firms should not renege on their implicit claims, even when these implicit agreements are not legally binding. First, a firm's value depends on its reputation for honoring its promises to non-financial stakeholders (Telser, 1980; Cornell and Shapiro, 1987; Maksimovic and Titman, 1991). While a failure on the part of the firm to adopt and maintain employeefriendly practices will not increase the risk of distress, it will most likely result in dissatisfied workers, an increased risk of high employee turnover, and ultimately a loss of reputation in the labor market (Shapiro and Titman, 1986). It is this loss of reputation with employees in particular and non-financial stakeholders in general that will lead to a decrease in the value of implicit claims sold to new stakeholders, resulting in a decline in future cash flows and the value of the firm (Cornell and Shapiro, 1987; Bowen, DuCharme, and Shores, 1995).

Second, meeting and maintaining high standards of employee treatment is becoming increasingly important for many firms due to the changing nature of the firm, human capital having become one of its most valuable assets (Zingales, 2000). "New" firms are more human-capital-intensive and operate in an increasingly competitive environment (Zingales, 2000). This increased competition creates a greater need for innovation and quality improvements, which in turn provide firms with stronger incentives to enhance employees' innovative efforts by committing to their well-being (Turban and Greening, 1997; Lawler, 
2008). ${ }^{1}$ Consistent with this observation, Falato, Kadyrzhanova, and Sim (2012) show that the structural shift in the U.S. economy toward intangible capital over the last few decades can provide an explanation for the increase in corporate cash holdings over time.

The notion that firms can use conservative financial policies (e.g., large cash holdings) to signal their commitment to honor their promises to current and potential employees is in line with empirical evidence in the literature. Holder, Langrehr, and Hexter (1998) find that firms adopt conservative dividend policies to signal that they have the necessary cash to make payoffs on implicit claims. Brown and Matsa (2013) show that job seekers are able to accurately perceive firms' financial health and that the volume and quality of applicants attracted to open job postings decline when firms become distressed. It is therefore challenging for firms with weak financial health to recruit for jobs with demanding educational requirements and to retain quality employees as the latter will seek more stable work elsewhere. The authors stress that these labor-related costs provide firms with a strong incentive to adopt more conservative financial policies.

The abovementioned arguments suggest that firms have incentives to accumulate cash reserves in order to signal their ability to maintain and improve the employee welfare benefits they provide. We argue that cash holdings play a more important role than alternative financial policies, such as lines of credit, hedging, and unused debt capacity, in reassuring workers that firms can honor implicit claims. ${ }^{2}$ Consistent with the stakeholder theory, the value of implicit claims associated with labor is expected to be higher for firms that assign more importance to their workforce, which is part of their intangible capital. Note, however,

\footnotetext{
${ }^{1}$ See also Passov (2003), who was treasurer of Pfizer at the time that paper was written, for a discussion of the importance for knowledge companies of having large cash balances.

${ }^{2}$ Almeida, Campello, Cunha, and Weisbach (2014) discuss why firms prefer cash to other liquidity management alternatives as a way to ensure sufficient liquidity for future investments. Demiroglu and James (2011) review recent empirical evidence that suggests that lines of credit are an imperfect substitute for cash holdings.
} 
that intangible capital cannot easily be verified or liquidated and, as such, cannot be pledged as collateral in order to raise debt financing (Falato, Kadyrzhanova, and Sim, 2012; Rampini and Viswanathan, 2013). By accumulating large cash balances, a firm that is strongly committed to employee well-being, and as a result invests heavily in non-collateral intangible capital, can credibly signal that it has the financial flexibility to maintain investment in employee-friendly practices and honor implied promises about fair employee treatment.

To empirically examine the relation between a firm's commitment to employee wellbeing and its cash holdings, we follow recent studies in corporate finance (e.g., Verwijmeren and Derwall, 2010; Bae, Kang, and Wang, 2011; Faleye and Trahan, 2011) and create an employee welfare index (hereafter EWI) to proxy for a firm's employee-friendly practices, using employee relations ratings provided by the KLD STATS database (hereafter KLD). According to our prediction, the greater is a firm's commitment to employee well-being, as measured by a higher EWI score, the greater will be its incentive to hold cash.

Using a sample of 13,752 firm-year observations for the period 2003-2009 for which KLD ratings are available, we find strong evidence that firms hold more cash when they have a higher EWI score, that is, when they maintain higher standards of employee welfare. The results are economically significant: a one-point increase in EWI (with a standard deviation of 0.855 points) is associated with an increase in cash holdings of $1 \%$ (in absolute terms) or $7.94 \%$ (relative to the median). This positive relation is robust to a variety of model specifications. Moreover, it is more pronounced in industries in which human capital is crucial to the firm's business, which is consistent with the predictions of stakeholder theory. In particular, the effect of EWI on cash holdings is positive and significant only for humancapital-intensive firms, and for firms in human-capital-intensive industries such as the telecoms, healthcare, and high-tech industries. Further, EWI explains cash-holding choices only in highly competitive and high-labor-mobility industries. 
In order to better establish the channel of the EWI - cash holdings relation, we next investigate the role of distress risk and financial constraints. Following Arnold (2014), we argue that the positive effect of EWI on cash holdings will be less pronounced for economically distressed firms than for their non-distressed counterparts since it could be too expensive for the former firms to accumulate cash in the face of distress risk. We expect distressed firms to draw on their cash in order to service debt instead of investing it in future investment opportunities (Arnold, 2014), which should weaken the EWI - cash relation. Using alternative proxies for economic distress, we indeed find that the impact of EWI on cash holdings is more pronounced for non-distressed firms.

Next, motivated by Davydenko's (2013) analysis of the interaction between economic distress and financial constraints, we predict that, among the non-distressed firms, those that are constrained will have the strongest incentive to signal their ability to maintain and improve the levels of employee welfare benefits they provide, and at the same time will be able to afford to do so. In line with the precautionary savings motive (Almeida, Campello, and Weisbach, 2004, 2011; Han and Qiu, 2007), we argue that constrained firms should hold liquid assets as a valuable buffer to safeguard against future cash flow volatility that may affect their ability to honor implicit claims related to employee welfare, even if these claims are foreseeable. Consistent with this prediction, we find the impact of EWI on cash holdings to be stronger for constrained (non-distressed) firms than for their unconstrained counterparts. This result is robust to using alternative proxies for financial constraints.

One major concern that could undermine the importance of our findings is the potential endogeneity of EWI. The employee-related practices of a firm could be related to unobservable factors affecting its cash holdings, leading to a spurious correlation. For example, firms may invest in employee benefits and maintain high employee relations ratings while building up large cash reserves due to good financial performance. Reverse causality 
poses another, similar concern. It could be that firms do not take employee welfare into account when implementing cash policies; in contrast, firms with excess or free cash have the luxury of investing in employee-friendly practices (Hong, Kubik, and Scheinkman, 2012). We address these endogeneity concerns in a number of ways. First, we adopt an instrumental variable approach in which we use firm-level (10-year-) lagged pension and retirement expenses and industry-level wage rates as instruments. Second, we create an alternative, exogenous index for the quality of employee treatment using state laws on wrongful discharge, health and safety, and family leave. We conjecture that firms in states with stringent laws have an (exogenous) obligation to be more employee-friendly and thus exert more effort towards employee welfare. Third, we perform an out-of-sample test to investigate whether a firm's inclusion in the Fortune magazine list of the "100 Best Companies to Work For" between 1998 and 2011, which we use as a proxy for a firm's investment in employee benefits, has a positive effect on the firm's cash holdings. We find that the impact of employee welfare standards on cash holdings is robust to these additional tests.

Our paper makes the following contributions to the literature. First, we provide novel evidence that firms' commitment to employee well-being affects their cash-holding choices. To the best of our knowledge, only two studies, by Klasa, Maxwell, and Ortiz-Molina (2009) and Schmalz (2013), empirically examine the interaction between cash holdings and labor relations. Klasa, Maxwell, and Ortiz-Molina (2009) find that firms facing stronger unions strategically hold less cash in order to improve their bargaining position with these unions. Our paper has a different focus because we examine the non-bargaining effect of employee treatment on cash holdings. Schmalz (2013) examines the relation between cash holdings and unionization, taking into account firms' incentive to manage human capital risk. He shows how cash holdings can help firms regain financial flexibility following an exogenous increase in labor rigidity after unionization. Our analysis is different from that of Schmalz (2013) 
since we investigate the role cash plays in the honoring of implicit claims related to workplace quality.

Second, our study adds to the growing literature examining the interaction between firms' non-financial stakeholders and financial decisions, in particular capital structure (Titman, 1984; Titman and Wessels, 1988; Barton, Hill, and Sundaram, 1989; Kale and Shahrur, 2007; Banerjee, Dasgupta, and Kim, 2008). This literature identifies several laborrelated factors affecting leverage, such as the human costs of bankruptcy (Berk, Stanton, and Zechner, 2010), strategic bargaining with labor unions (Matsa, 2010), labor market size (Kim, 2012), the use of temporary workers (Kuzmina, 2012), unemployment risk (Agrawal and Matsa, 2013), and employment protection laws (Simintzi, Vig, and Volpin, 2015). ${ }^{3}$ Nevertheless, it has not examined the equally interesting question of whether human capital also affects corporate cash policies. Our study attempts to fill this important gap by focusing on the interaction between employee welfare and cash holdings.

Our paper is closely related to, and complements, recent research documenting the association between fair employee treatment and conservative debt policies (Verwijmeren and Derwall, 2010; Bae, Kang, and Wang, 2011). Bae, Kang, and Wang (2011), in particular, find that firms that adopt employee-friendly practices, as measured by an employee treatment index constructed in a similar way to our EWI, maintain low debt ratios. Verwijmeren and Derwall (2010) further show that firms with leading track records in fair employee treatment reduce the probability of bankruptcy by using debt conservatively. We complement the evidence in those studies by showing that cash holdings can serve as an alternative financial channel through which firms can signal their commitment to honor implicit claims related to

\footnotetext{
${ }^{3}$ Another strand of literature looks at the impact of leverage on a number of labor-related variables, such as wages (Sharpe, 1994; Hanka, 1998; Hovakimian and Li, 2011; Chemmanur, Cheng, and Zhang, 2013), employment growth (Almazan, de Motta, and Titman, 2012), and workplace safety (Cohn and Wardlaw, 2012).
} 
employee welfare. Controlling for the relation between leverage and cash, we are able to disentangle the distinct effect of employee welfare standards on cash holdings. Our analysis further distinguishes the role of cash from that of leverage when there is distress risk. In particular, while Bae, Kang, and Wang (2011) find that low-leverage policies are an important signal of "reputation" for distressed firms, we show that conservative cash policies may not be available to such firms but may be affordable for their non-distressed counterparts who may use them as a signal of their commitment to fair employee treatment.

Finally, our study contributes to an established literature investigating the determinants of corporate cash holdings. Earlier studies identify a number of factors affecting cash policies, such as cash flow volatility, leverage, growth opportunities, and capital expenditure (Kim, Mauer, and Sherman, 1998; Opler, Pinkowitz, Stulz, and Williamson, 1999). More recently, new determinants such as product market competition (Haushalter, Klasa, and Maxwell, 2007), corporate diversification (Duchin, 2010; Tong, 2011), R\&D smoothing (Brown and Petersen, 2011), intangible capital (Falato, Kadyrzhanova, and Sim, 2012), customer relations (Itzkowitz, 2013), CEO inside debt (Liu, Mauer, and Zhang, 2014), refinancing risk (Harford, Klasa, and Maxwell, 2014), and banking deregulation (Francis, Hasan, and Wang, 2014) have been proposed. Our study identifies another important reason for firms to hold cash: their commitment to employee well-being.

The remainder of the paper is organized as follows. Section 2 describes the data and provides summary statistics. Section 3 reports and discusses the main empirical results. Section 4 presents several robustness tests and Section 5 concludes. 


\section{Data and Summary Statistics}

\subsection{Employee Welfare Index}

We use the KLD STATS (Statistical Tool for Analyzing Trends in Social \& Environmental Performance) database to construct our EWI. ${ }^{4}$ KLD screens all companies in the S\&P 500 Index and the Domini 400 Social Index (DS 400), as well as the 3,000 largest publicly traded U.S. companies by market capitalization, and provides extensive annual social responsibility ratings for firms in seven major qualitative areas, namely environment, community, product, corporate governance, diversity, employee relations, and human rights. ${ }^{5}$

Following recent corporate finance studies (e.g., Cronqvist, Low, and Nilsson, 2009; Landier, Nair, and Wulf, 2009; Verwijmeren and Derwall, 2010; Bae, Kang, and Wang, 2011; Faleye and Trahan, 2011; Ertugrul, 2013), we use KLD's ratings on 'Employee Relations" as a proxy for employee well-being. More specifically, we calculate EWI by summing identified strengths and subtracting identified concerns included in the "Employee Relations" dimension in a given year (Verwijmeren and Derwall, 2010; Faleye and Trahan, 2011). Based on Ertugrul (2013), we further include the "work/life benefits" variable from the "Diversity" dimension. ${ }^{6}$

Below are the components of our index as described by KLD:

\footnotetext{
${ }^{4}$ An alternative approach to measuring investment in human capital and employee treatment would be to use the level of expenditure on employee welfare. However, due to the lack of comprehensive accounting measures for such expenditure, most studies in corporate finance use employee relations ratings instead (e.g., Verwijmeren and Derwall, 2010; Bae, Kang, and Wang, 2011).

${ }^{5}$ KLD analysts review a company's public documents, including the annual report, proxy, company website, and corporate social responsibility (CSR) reporting, in addition to government and non-government organization data. They also monitor media sources on a daily basis for developing issues, and employ a proprietary framework to assign the ratings.

${ }^{6}$ In unreported robustness checks, we try out many variations of the index as suggested by previous studies. For example, following Bae, Kang, and Wang (2011) and Ertugrul (2013), we use an index including strength variables only. Our results are robust to these variations.
} 


\section{"Strengths:}

1. Union relations strength: the company has taken exceptional steps to treat its unionized workforce fairly.

2. Cash profit sharing: the company has a cash profit-sharing program through which it has recently made distributions to a majority of its workforce.

3. Employee involvement: the company strongly encourages worker involvement and/or ownership through stock options available to a majority of its employees; gain sharing, stock ownership, sharing of financial information, or participation in management decision making.

4. Retirement benefits strength: the company has a notably strong retirement benefits program.

5. Work/life benefits: the company has outstanding employee benefits or other programs addressing work/family concerns (e.g., childcare, elder care, or flextime).

\section{Concerns:}

1. Union relations concern: the company has a history of notably poor union relations.

2. Health and safety concern: the company recently has either paid substantial fines or civil penalties for willful violations of employee health and safety standards, or has been otherwise involved in major health and safety controversies.

3. Workforce reductions: the company has made significant reductions in its workforce in recent years.

4. Retirement benefits concern: the company has either a substantially underfunded defined benefit pension plan, or an inadequate retirement benefits program.

5. Other concern: the company is involved in an employee relations controversy that is not covered by other KLD ratings." 
We note that all of the above employee-related categories are related to noncontractual specific programs or informal practices, thus capturing implicit claims towards employees. $^{7}$ In the KLD database, each of the categories receives a rating of either 0 or 1 . To arrive at our EWI, we sum up the KLD ratings for the five "strength" categories and subtract the ratings for the five "concern" categories, creating an index ranging from -5 to 5 . By construction, higher values of EWI indicate better employee welfare.

Table 1 presents summary statistics for the EWI and its components. The average EWI score in our sample is -0.312 . Further, $53.5 \%$ of firm-year observations in the sample have a neutral (zero) EWI score, $36.1 \%$ have a negative score and $10.3 \%$ have a positive score. Finally, no firms in the sample have an EWI score of 5 or -5 . Our summary statistics on the EWI score are generally consistent with previous studies using a similar index (e.g., Verwijmeren and Derwall, 2010).

$<$ Insert Table 1 around here $>$

\subsection{Other Variables}

The dependent variable in our study, cash holdings, is measured as the ratio of cash and short-term investments (che) to total assets (at). Our results are robust to the use of alternative measures of cash holdings including the ratio of cash to net assets, the logarithm of the ratio of cash to net assets, and the ratio of cash to sales. ${ }^{8}$ Following Bates, Kahle, and Stulz (2009), we control for the following firm-specific characteristics in our regressions:

- Cash flow: measured as earnings after interest, dividends, and tax but before depreciation $(o i b d p-x i n t-t x t-d v c)$ scaled by total assets $(a t)$.

\footnotetext{
${ }^{7}$ In an unreported robustness check, we exclude the cash profit sharing and retirement benefits components from our index as they may arguably be explicit in nature in some firms. Our results are robust to the use of this alternative index.

${ }^{8}$ The results for the alternative measures are not reported, to conserve space, but are available upon request.
} 
- Net working capital: measured as working capital (wcap) minus cash (che), all scaled by total assets $(a t)$.

- Capital expenditure: measured as the ratio of capital expenditure (capx) to total assets $(a t)$.

- Leverage: measured as long-term debt $(d l t t)$ plus debt in current liabilities $(d l c)$, all scaled by the book value of assets $(a t) .^{9}$

- Acquisitions: defined as the ratio of acquisitions $(a q c)$ to total assets (at), with acquisitions reflecting only the associated cash outflows.

- Tobin's $q$ : proxied by the market-to-book ratio, in turn defined as the book value of assets (at) plus the market value of common equity $(\operatorname{prcc} f \times c s h o)$ minus the book value of common equity (ceq), all scaled by the book value of assets (at).

- Size: measured as the logarithm of the firm's book value of assets (at) in 2003 dollars.

- Industry cash flow volatility: calculated as the average of the standard deviation of firm-level cash flow in each industry defined by two-digit SIC code, the standard deviation in question being the standard deviation of the firm-level ratio of cash flow to assets for the previous five years.

- $R \& D$ expenditure: measured as the ratio of $\mathrm{R} \& \mathrm{D}$ expenses ( $x r d)$ to net sales (sale), and set equal to zero when R\&D expenses ( $x r d$ ) are missing. ${ }^{10}$

- Dividend payout: defined as a dummy variable, set equal to one in years in which a firm pays common dividends $(d v c)$, and zero otherwise.

\footnotetext{
${ }^{9}$ Our model controls for the association between EWI and leverage. In a robustness test (unreported), we apply the methodology of Acharya, Almeida, and Campello (2007) and find that the relation between EWI and cash remains significantly positive for a subsample of constrained firms with high hedging needs for which cash is distinct from negative debt. Thus, our results are not driven by explanations based on viewing cash as negative debt; that is, the relation between EWI and cash is distinct from the impact of EWI on leverage.

${ }^{10}$ Our results are robust to the addition of a dummy variable that distinguishes between firms that report R\&D expenses and non-reporting firms.
} 


\subsection{Sample Selection}

Our sample consists of all the firms covered by KLD between 2003 and 2009. KLD has been providing ratings since 1991 but in 2003 the database expanded its coverage to include the largest 3,000 U.S. companies by market capitalization. ${ }^{11}$ Our initial sample consists of 20,746 firm-year observations with ratings on employee welfare variables available. We then merge the list of these observations, with firm characteristics from Compustat. Next, we exclude firms for which information on total assets is missing. Consistent with the extant literature, we also exclude financial firms and utilities (firms with SIC codes between 6,000 and 6,999 and those with codes between 4,900 and 4,999). In order to mitigate the effect of outliers, we winsorize all Compustat variables at the $1^{\text {st }}$ and $99^{\text {th }}$ percentiles of their distributions. The final sample has 13,752 firm-year observations.

\subsection{Summary Statistics}

Panel A in Table 2 reports summary statistics for the dependent and control variables. The average and median cash holdings in our sample are $21.1 \%$ and $12.6 \%$, respectively. Bates, Kahle, and Stulz (2009) report similar figures; average (median) cash holdings range from $22.7 \%$ to $24.0 \%$ (13.3\% and $14.8 \%$ ) for the $2003-2006$ period in their sample. Panel B provides information on the correlations between our dependent variable, cash holdings, our variable of interest, EWI, and all the other explanatory variables. We find that the correlation between EWI and cash is positive (0.072). There is no sign of high correlation between our variable of interest, EWI, and the control variables, with the highest reported correlation equal to -0.062 (between EWI and leverage).

$<$ Insert Table 2 around here $>$

\footnotetext{
${ }^{11}$ In unreported results we obtain qualitatively similar findings when examining the KLD sample over the period 1995-2009.
} 
In Table 3, we compare the characteristics of firms with positive EWI scores to those of firms with negative EWI scores. Column 1 reports the averages for all observations in our sample. Column 2 provides the averages of the firm characteristics for observations with neutral EWI scores, most observations falling into this category $(7,371$ of the 13,752 observations). Column 3 reports the characteristics of firms with positive EWI scores while Column 4 presents the characteristics of firms with negative scores. Column 5 reports the pvalues for the $t$-test of differences in the means of the characteristics between firms with positive and negative EWI scores. ${ }^{12}$

The comparison reveals that firms with positive EWI scores hold more cash. The average cash holdings are $22.6 \%$ for positive-scoring firms compared to $20.2 \%$ for negativescoring firms. This difference is statistically significant at the $1 \%$ level. The 2.4 -percentagepoints difference is also economically significant considering that it amounts to almost $50 \%$ of the average firm's annual capital expenditure (5.3\%). Firms with a neutral score fall in the middle with an average of $21.5 \%$. The comparisons between the positive- and negativescoring firms also show that the former firms are bigger in size, pay out more in dividends, have better growth opportunities, lower net working capital, more conservative debt policies, lower tangible assets, and higher cash flows, and operate in industries with more volatile cash flows.

\section{$<$ Insert Table 3 around here $>$}

\section{Empirical Results}

\subsection{Cash Holdings and Employee Welfare Standards}

Table 4 presents the results on the effect of EWI on cash holdings. We report p-values based on heteroskedasticity-robust standard errors clustered at the firm level. All regressions

\footnotetext{
${ }^{12}$ Tests based on median firm characteristics provide similar results, but are not reported to conserve space.
} 
include year dummies but to save space we do not report their estimates. In Models 1-3, we run OLS regressions. In Model 1, we regress cash holdings on the control variables presented in Subsection 2.2. The coefficients on these firm characteristics are statistically significant and have signs in line with existing evidence in the literature (Bates, Kahle, and Stulz, 2009). Specifically, firm size, net working capital, and dividend payout have negative coefficients as expected, while the estimated coefficients on market-to-book value, industry cash flow volatility, and R\&D are positive and significant. Prior research suggests that the effects of cash flow, capital expenditure, leverage, and acquisitions on cash holdings are ambiguous; we find in our sample that these variables all have negative coefficients, again consistent with Bates, Kahle, and Stulz (2009).

In Model 2, we include EWI as an additional explanatory variable. The coefficient estimate for EWI is positive and highly significant. In addition, the coefficients of the control variables are very similar to those in Model 1, suggesting that the impact of EWI on cash holdings is not driven by the index's correlation with other firm characteristics. The results regarding EWI are also economically significant. A one-point increase in EWI (with a standard deviation of 0.855 points) is associated with a $1 \%$ increase in cash holdings. Considering that the median (mean) cash holdings are $12.6 \%(21.1 \%)$, this amounts to an economic impact of $7.94 \%(4.74 \%){ }^{13}$

In Model 3, we estimate a cross-sectional regression of the time-series average of cash holdings on the time-series average of EWI as well as the time-series averages of the other explanatory variables. The coefficient on EWI remains positive and statistically significant, suggesting that there is a cross-sectional relation between EWI and cash holdings.

\footnotetext{
13 Our variable of interest, EWI, exhibits little time-series variation. Thus, most of our reported model specifications focus on exploring the cross-sectional relation between the EWI and cash holdings.
} 
To capture the variation in the effect of EWI on cash holdings across industries, Model 4 employs a specification similar to Model 3 but uses industry averages instead of firm-specific averages, the industries being defined by six-digit industry NAICS codes. The coefficient on EWI is again significantly positive, and similar in magnitude to those in previous models (0.013), indicating that the effect of EWI on cash holdings varies across different industries.

In Model 5, we run a Fama-MacBeth regression and find that the coefficient on EWI remains significantly positive. In unreported analysis, we also re-estimate Model 5 by replacing EWI with its ten individual components. Six out of the ten individual components have a significant impact on cash holdings. The only exceptions are "union relations strength", "retirement benefits strength", "retirement benefits concern", and "workforce reductions", for which the effects are insignificant. We hence conclude that the positive relation between employee welfare standards and cash holdings is not driven by a single subcategory of the index.

In Model 6, we re-estimate the specification of Model 2, but this time exclude firms with neutral EWI scores to make sure that our earlier results were not driven by the inclusion of these firms. We obtain qualitatively similar results: each extra point on the EWI raises cash by 1.2 percentage points, ceteris paribus.

Overall, our findings are qualitatively similar across a variety of models: employee welfare standards have a robust, positive impact on cash holdings. This evidence is consistent with the stakeholder theory prediction that firms strategically hold more cash to signal their willingness to meet and maintain their commitment to employee well-being.

$<$ Insert Table 4 around here $>$ 


\subsection{Why Do Firms That Treat Their Employees Better Hold More Cash?}

In this section, we first conduct additional tests of the stakeholder theory prediction regarding the positive relation between employee welfare benefits and cash holdings. Specifically, we examine whether this relation is more pronounced for firms in humancapital-intensive, competitive, or high-labor-mobility industries in which employees are more important to their businesses. Next, we refine the channel of the EWI - cash holdings relation by investigating the impact of distress risk and financial constraints on the strength of a firm's commitment to honor implicit claims related to employee well-being.

\subsubsection{Human Capital Intensity, Industry Competition, and Labor Mobility}

We first examine the impact of employee welfare standards on cash holdings for firms with high versus low human capital intensity. The stakeholder theory suggests that the impact of employee welfare standards on cash holdings should be stronger for human-capitalintensive firms, which have greater incentives to retain and motivate their workers. We measure the human capital intensity of the firm using the ratio of $R \& D$ expenditure to total sales, since R\&D-intensive firms are more likely to depend on highly skilled employees and require higher levels of expertise and education. We define human-capital-intensive firms as firms with above-median R\&D expenditure to total sales. The first and second columns in Table 5 present the results of the regressions for the two subsamples based on the R\&D intensity. We find the coefficient on employee welfare to be positive and significant for the subsample of firms with high human capital intensity (0.013), while it is much smaller (0.003) and statistically insignificant for the subsample with low human capital intensity. The difference between the two coefficients is significant at the $5 \%$ level.

We also split the firms into two subsamples based on whether they belong to a human-capital-intensive industry or not. Following Ertugrul (2013), we define humancapital-intensive industries to include all subcategories of the telecommunications, high-tech, 
and healthcare industries. ${ }^{14}$ Columns 3 and 4 in Table 5 show that the coefficient on EWI is significantly larger in these human-capital-intensive industries $(0.019)$ than in the remaining industries (0.005).

Next, we look at whether employee welfare has a more important influence on cash holdings in highly competitive industries. The motivation for investing in employee benefits is expected to be higher for firms operating in competitive industries because these firms face a greater risk of losing their valuable human capital to rivals than do firms in concentrated industries whose labor markets offer limited opportunities for workers to switch employers within the industry. This loss of valuable employees can hurt firms' competitiveness through the unwanted dissemination of proprietary information to rivals (Brown and Petersen, 2011) and, more generally, a loss in firms' organizational capital (Eisfeldt and Papanikolaou, 2013). Since the motivation for keeping valuable human capital and committing to employee welfare is expected to be higher for firms in competitive industries, a stronger relation between EWI and cash holdings should be observed. To test this hypothesis we use the HerfindahlHirschman Index to split our sample firms by the intensity of industry competition using four-digit SIC codes. We follow Frésard (2010) and define competitive industries as those with an index score below 1,000 and concentrated industries as those with a score above 1,800. Columns 5 and 6 in Table 5 show that the coefficient on EWI (0.015) is only significant for competitive industries, suggesting that the relation between employee welfare and cash holdings only exists for firms that have difficulty retaining employees.

We next examine the effect of employee treatment on cash holdings for firms in lowversus high-labor-mobility industries. The relation between a firm's commitment to

\footnotetext{
${ }^{14}$ We specifically include the following two- and three-digit SIC codes: $283,357,36,384,48$, and 80 . We obtain qualitatively similar results if we instead use the Fama-French 48-industry classification to define those industries.
} 
employee well-being and its cash holdings should be affected by the flexibility workers have to walk away from their employers in response to better job opportunities. Lambrecht and Pawlina (2013) argue that firms have become more dependent on transferable human capital, and that this change in the nature of the company may be responsible for the conservative debt policies observed in many firms. We thus argue that firms in labor-mobile industries need to exert more effort to retain their human capital and, therefore, have more incentive to treat their employees better. One needs to be cautious, though, when testing for the moderating effect of labor mobility as it may be confounded by the skill level of labor within the industry. Titman and Wessels (1988) argue that firms in industries with low quit rates tend to employ workers with high levels of job-specific human capital. In a similar vein, Bae, Kang, and Wang (2011) argue that employees are, on average, better educated and more skilled in low-turnover industries. Therefore, it is important to control for labor skill when examining the impact of labor mobility on the relation between employee treatment and cash holdings.

To test for the hypothesis that the effect of EWI on cash is more pronounced in highlabor-mobility industries, while controlling for labor skill, we focus on a subsample of firms operating in industries with highly skilled labor. To measure the skill level of labor within an industry, we follow Ochoa (2013), and Belo and Lin (2013), and use Occupational Employment Statistics (OES) data from the Bureau of Labor Statistics and the U.S. Department of Labor's O*NET program classification of occupations by skill level to construct an industry-specific labor skill index (Labor_Skill). ${ }^{15}$ This index captures the employee-weighted average skill level in a particular industry. For each year, we define firms employing a high share of skilled labor as those in the top $30^{\text {th }}$ percentile of Labor_Skill. For

\footnotetext{
${ }^{15}$ The O*NET occupational classification is based on how much education, related work experience, and training an employee would need to perform a given job at a competent level.
} 
the subsample of skill-dependent firms, we then define, for each year, firms with labor mobility in the top (bottom) $30^{\text {th }}$ percentile as belonging to high (low)-mobility industries. To measure labor mobility, we use the construct introduced by Donangelo (2014), ${ }^{16}$ which captures the ex-ante flexibility that workers in a given industry have to move across industries (i.e., whether an industry is characterized by portable labor skills).

Columns 7 and 8 in Table 5 report the results of the regressions for the two subsamples of skill-dependent firms sorted by labor mobility. As expected, the coefficient on employee welfare is positive and significant for the high-labor-mobility industries (0.018) but is negative (-0.002) and statistically insignificant for the low-labor-mobility industries.

In sum, our results in this subsection support the stakeholder theory prediction that the impact of EWI on cash holdings will be stronger in industries in which human capital is firmspecific and valuable to business success.

$<$ Insert Table 5 around here $>$

\subsubsection{The Role of Distress Risk and Financial Constraints ${ }^{17}$}

In this section we attempt to further refine the channel of the EWI - cash holdings relation. We argue that the firm's ability to showcase its commitment to employee well-being by accumulating cash reserves is affected by certain firm characteristics and financial policies. We first examine the impact of distress risk. We focus on the effect of economic distress, as opposed to financial distress, since financially distressed firms already face a cash shortage and will as a result find it prohibitively expensive to accumulate cash. We argue that the positive effect of EWI on cash holdings will be less pronounced for economically distressed firms than non-distressed ones since it could be too expensive for the former to build up cash reserves in the face of distress risk. Our argument builds on the prediction in

\footnotetext{
${ }^{16}$ We thank Andres Donangelo for sharing his data.

${ }^{17}$ We thank the reviewer for encouraging us to pursue this line of enquiry.
} 
Arnold (2014) that firms faced with economic distress tend to draw on their cash holdings in order to service debt obligations, rather than using them to finance future investment opportunities. The reasoning behind this prediction is that, in the presence of agency conflicts, equity holders have less incentive to inject funds into distressed firms, which forces managers to burn through cash so as to defer default. The notion that firms use their cash to service debt during distress is also in line with Harford, Klasa, and Maxwell's (2014) conjecture that firms faced with tight credit conditions and refinancing risk may draw on their cash holdings. Overall, our argument suggests that the signal about fair employee treatment is most likely to be affordable for non-distressed firms.

We present the test results for this prediction in Panel A of Table 6. Following Davydenko (2013), we use the two most relevant measures of economic distress. ${ }^{18}$ The first is the market value of assets relative to the face (book) value of debt (Davydenko, 2012, 2013). Given that we do not have the observed market prices of bonds and bank loans for our extensive panel, we follow the conventional definition in the capital structure literature and proxy for the market value of assets using the book value of total assets plus the market value of equity minus the book value of equity (e.g., Flannery and Rangan, 2006; Strebulaev and Yang, 2013). ${ }^{19}$ A limitation of this construct is that it does not account for the expected default costs (Davydenko, 2012; Davydenko, Strebulaev, and Zhao, 2012). However, given that the expected cost of default is only a modest fraction of total assets, any error in the

\footnotetext{
${ }^{18}$ In untabulated analysis we also use the financial crisis of 2007-2009 as a proxy for economic distress. Our expectation is that during the crisis there was an increase in the incidence of economic distress for the average firm, thus weakening the EWI - cash holdings relation. Indeed, our evidence supports this prediction, i.e., the effect of EWI on cash is more pronounced pre-crisis, when there were lower levels of economic distress.

${ }^{19}$ This measure is likely to be biased toward classifying low-leverage firms as non-distressed, although such firms may still become economically unviable and go out of business (Senbet and Wang, 2012). This bias is non-negligible because a considerable fraction of firms adopt conservative debt policies (Strebulaev and Yang, 2013). We thus deal with this problem by excluding firms with leverage in the $0 \%-5 \%$ range.
} 
estimated market value of assets is unlikely to exceed a few percentage points (Davydenko, 2012, 2013). Thus, we argue that our measure is an acceptable approximation of the theoretical assets-to-debt ratio. The second proxy for economic distress is a firm's implied probability of default, which is calculated using the market-implied distance to default measure advanced by Bharath and Shumway (2008). We define firms with above (below) median market value of assets relative to debt and firms with zero (greater than zero) default probability as non-distressed (distressed).

The results reported in Panel A of Table 6 are in line with our prediction. In particular, the EWI - cash holdings relation is stronger for non-distressed firms than for their distressed counterparts. The difference in the EWI coefficients between non-distressed and distressed firms is statistically and economically significant. In Models 3-4 and 7-8, we control for asset volatility instead of cash flow volatility because the former variable may better capture the probability of economic distress (Davydenko, 2012). We find that asset volatility is significant in all models and, more importantly, our main results regarding the effects of EWI on cash holdings continue to hold.

We next focus on the joint impact of economic distress and financial constraints on the relation between EWI and cash holdings. Our test is influenced by Davydenko's (2013) analysis of how cash shortages result in default in the presence of both distress and constraints. We predict that, among the non-distressed firms, those that are financially constrained will have the strongest incentive to signal their ability to maintain and improve employee welfare standards, and at the same time will be able to afford to do so. Our conjecture regarding the effect of financial constraints on optimal cash policies is consistent with the conventional precautionary motive for holding cash (Almeida, Campello, and Weisbach, 2004, 2011; Han and Qiu, 2007). Even if the cash needs for employee welfare benefits are foreseeable, financially constrained (non-distressed) firms still have strong 
incentives to adopt conservative cash policies to reassure their workers about their ability to maintain welfare standards when they are faced with future cash flow volatility.

In Panel B of Table 6, we present the results of our tests relating to this prediction. In Models 1-4 (5-8), we measure economic distress using the assets-to-debt ratio (default probability). We measure the degree of financial constraint using the Whited and $\mathrm{Wu}$ (2006) (WW) index. ${ }^{20}$ For each year, we define firms with above (below) median scores on the WW index as constrained (unconstrained). The results in Models 1-2 show that the EWI - cash holdings relation is only significant for the non-distressed firms that are constrained, and not for those that are unconstrained. In Models 5-6, the impact of EWI on cash also seems to be stronger for the non-distressed and constrained group. Further, this finding remains unchanged when we control for the volatility in assets (Models 3-4 and 7-8). Overall, these results are broadly consistent with our prediction, and reveal the extent to which cash holdings are useful as a signal about fair employee treatment; i.e., they demonstrate that conservative cash policies are most relevant for non-distressed and constrained firms.

$<$ Insert Table 6 around here $>$

\section{Robustness Tests}

In this section, we report the results of several robustness tests that further verify the positive effect of employee welfare on cash holdings. We first report the results of the tests that help mitigate endogeneity concerns about the EWI. We next discuss the results obtained using an alternative measure of employee welfare benefits.

\footnotetext{
${ }^{20}$ The Whited and $\mathrm{Wu}(2006)$ index is defined as $-0.091 \times$ Cash Flow $-0.062 \times$ Dividend Dummy $+0.021 \times$ Long-Term Debt $-0.044 \times$ Size $+0.102 \times$ Industry Sales Growth $-0.035 \times$ Sales Growth. In untabulated analysis, we also use the payout ratio and bond ratings as proxies for financial constraints. Our results remain unchanged.
} 


\subsection{Endogeneity Concerns about the Employee Welfare Index}

One major concern that could undermine the importance of the findings reported so far is the potential endogeneity of the EWI. The employee welfare practices of the firm could be endogenously chosen and might be related to unobservable factors that also determine cash holdings, leading to a spurious correlation. For example, firms with good financial performance can maintain excellent standards of employee welfare and a high EWI score and, at the same time, build up large cash reserves. Reverse causality poses a similar concern. It may be the case that firms do not take employee welfare into account when implementing cash policies; in contrast, firms with excess or free cash may simply have the luxury of investing in employee-friendly practices (Hong, Kubik, and Scheinkman, 2012). To mitigate these endogeneity concerns, we follow previous studies and perform several robustness tests, as follows.

\subsubsection{Two-Stage Least Squares Regressions}

As a first test, we repeat our analysis using instrumental variables. We run two-stage least squares (2SLS) regressions using firm- and industry-level instruments. Following Bae, Kang, and Wang (2011), our firm-level instrumental variable is the logarithm of 10-yearlagged pension and retirement expenses per worker. This instrument is directly related to two components of our EWI, namely, "retirement benefits strength" and "retirement benefits concern". Given that Bae, Kang, and Wang (2011) argue that a firm's pension policy is likely to be relatively persistent over time, we expect to find a positive relation between our firmlevel instrument and the EWI score. Further, the 10-year-lagged pension and retirement expenses per worker should serve as a valid instrument for EWI because a firm's pension policy 10 years ago should not affect its contemporaneous level of cash other than through its correlation with current pension policies. 
Our second instrumental variable is the logarithm of industry-level wages, which we calculate as total labor and related expenses divided by total employees across firms in the same industry. Bae, Kang, and Wang (2011) explain that firms that pay higher wages are more likely to implement employee welfare policies because employees in such firms are likely to show higher productivity, which in turn leads the firms to treat them fairly. Using industry-level instead of firm-level wage rates also sidesteps the problem of missing data on firm-level labor and related expenses. Besides, although a firm's wage level could be related to its cash holdings, the industry-level wage is unlikely to be so.

The results for the 2 SLS regressions are presented in Table 7. In the first two models we use each of our two instruments to predict EWI in the first stage. In Model 3 we use the two instruments together. The results from the first-stage regressions show that our two instruments have positive and significant impacts on EWI, as expected. The second-stage regressions in all models confirm our previous finding that EWI has a significantly positive impact on cash holdings. ${ }^{21}$ It is also worth noting that the coefficients on EWI have increased significantly in magnitude under the instrumental variable specifications. The lowest of the coefficients in all three models, 0.053 in Model 1, is five times bigger than the OLS coefficient in the second model of Table $4(0.010)$. In summary, EWI continues to be positively related to cash holdings, even after controlling for endogeneity.

$<$ Insert Table 7 around here $>$

\subsubsection{Exogenous Index for Employee Treatment}

To further alleviate the endogeneity concerns, we create an exogenous welfare index and test its influence on cash holdings. To construct this index we rely on three sets of federal

\footnotetext{
${ }^{21}$ For Model 3, the test of over-identifying restrictions $(\mathrm{J}$-statistic $=0.32)$ fails to reject the joint null hypothesis that our two instruments are uncorrelated with the error term and are correctly excluded from the second-stage regression. Thus, we conclude that our instruments are valid.
} 
labor laws and exploit the state-level variation in the adoption and extension of these laws. The first set of these laws are state "Wrongful Discharge Laws" (WDL), which are commonlaw exceptions to the employment-at-will doctrine passed in several U.S. states since the 1970s. These exceptions can raise hurdles against firms' wrongful discharging of employees, making it more costly to dismiss employees, thereby increasing job security and limiting "workforce reductions", a component of our original EWI. There are three exceptions to the employment-at-will doctrine: the public policy exception, the implied contract exception, and the good faith exception; a state can choose to adopt none to all of these exceptions. ${ }^{22}$

The second set of these laws is related to the Occupational Safety and Health Act (OSHA) of 1970. Instead of adopting federal standards, U.S. states may elect to develop their own unique occupational safety and health programs. The 25 states and territories that operate state programs take responsibility for developing and enforcing occupational safety and health standards in their jurisdiction, and for providing consultative services. They also conduct free training and education programs, encouraging employers and employees to use safe and healthy work practices. Some of these states also require employers to establish safety and health programs.

Finally, the third set of laws we use to construct our exogenous index relates to the Family and Medical Leave Act (FMLA) of 1993. The variation in the strength of family leave laws by state comes from the variation in the extensions to the FMLA that different states have passed. These states have surpassed the federal government standards by expanding access to leave and providing other forms of workplace support for new parents. Based on the ratings given to different states by the "National Partnership for Women \& Families", we

\footnotetext{
${ }^{22}$ Acharya, Baghai, and Subramaniam (2014) show that these laws spur innovation and new firm creation. Autor, Donohue, and Schwab (2006) provide a detailed description of these laws.
} 
define California, Connecticut, Hawaii, Maine, Minnesota, New Jersey, Oregon, Rhode Island, Vermont, and Washington as states with strong laws on family leave. ${ }^{23}$

The rationale for using this exogenous index is that firms in states with strong employee protection laws, family leave laws, and occupational health and safety laws are exogenously obliged to be more employee-friendly and to exert more effort towards employee well-being. Therefore, the existence of tougher regulations will result in firms having a higher motive to hold cash, namely, in order to maintain the required standards of welfare provision and to avoid penalties for non-compliance. Importantly, this index mitigates the concern about employee welfare being endogenously determined. ${ }^{24}$

To construct our exogenous index we create five dummy variables. For each of the three WDL exceptions we create a dummy variable that takes the value of 1 if a firm is in a state that has adopted the exception. We then create a dummy variable that equals 1 if a firm is in one of the 25 states and territories that have their own unique occupational safety and health programs. The last dummy variable we create takes the value of 1 if a firm is located in a state with strong laws on family leave. Finally, we construct our index by summing up the five dummy variables. The index ranges from 0 to 5 , with higher values indicating stronger regulations for employee well-being.

Table 8 presents the results for the effect of the exogenous welfare index on cash holdings. The specifications of Models 1 to 4 are similar to that of Model 2 from Table 4, except that in Models 1-3 in Table 8 we replace our original EWI with each component of the exogenous index, and in Model 4 of Table 8 we replace EWI with the exogenous index. The

\footnotetext{
${ }^{23}$ For details, see the report entitled "Expecting Better: A State by State Analysis of Laws That Help New Parents" (www.nationalpartnership.org). We use the report published in May 2012.

${ }^{24} \mathrm{We}$ are unable to exploit changes in U.S. labor laws as an exogenous source of variation or a structural break in the quality of employee treatment because there were no major changes in U.S. labor laws during our sample period.
} 
results reveal that the coefficients of the variables of interest (i.e., the exogenous index and its components) are significantly positive in all four models, suggesting that firms hold more cash when they are located in states with stronger employee protection laws, family leave laws, or occupational health and safety laws. This finding is consistent with the earlier results obtained using the KLD data.

\section{$<$ Insert Table 8 around here $>$}

\subsection{Alternative Measure of Employee Welfare Standards}

In this section, we further check the robustness of the results by performing an out-ofsample test using firms in Fortune magazine's list of the "100 Best Companies to Work For" between 1998 and 2011. This list consists of companies known for their employee-friendly practices and strong commitment to employee well-being, companies we expect to show a tendency to hold more cash. Applying the same data restrictions as were used for the KLD sample yields a final sample of 105,532 firm-year observations.

Panel A of Table 9 presents the results from the regression analysis in which we examine the effect of inclusion in Fortune's list on cash holdings. We create a dummy variable equal to 1 if a firm appears in the list in a given year. In Models 1 to 4 , we regress cash holdings on the variable of interest, the Fortune dummy, and the control variables. In Model 1, we run an OLS regression with year dummies. In Model 2, we further include industry dummies to control for industry fixed effects. In Model 3, we run a cross-sectional regression of the time-series average of cash holdings on the time-series averages of the explanatory variables. In Model 4, we run a Fama-MacBeth regression. The coefficient estimate for the Fortune dummy is positive and highly significant in all four models, ranging from 0.043 to 0.110 . Further, the coefficients on the other explanatory variables have the expected signs and are statistically significant. 
Since the characteristics of firms included in Fortune's list may differ from the other firms in our sample, we further use propensity score matching to test for the difference in cash holdings between firms in Fortune's list and matched firms in Compustat. The variables used to perform the matching are the control variables from our baseline regression. In Panel B of Table 9 we report the differences in cash holdings between Fortune and matched (nonFortune) firms. Depending on the matching technique used (i.e., nearest neighborhood or Gaussian kernel matching), we find that, on average, the cash holdings of Fortune firms are 1.3 to 2.9 percentage points higher than matched (non-Fortune) firms. In sum, the results suggest that a firm's investment in employee well-being, measured by its inclusion in the Fortune list, has a positive effect on its cash holdings, thus corroborating our previous findings using the KLD index.

$<$ Insert Table 9 around here $>$

\section{Conclusion}

We investigate whether a firm's commitment to fair employee treatment affects its cash holdings. According to the stakeholder theory, firms with a strong commitment to employee well-being have incentives to hold more cash in order to signal their ability to honor their implied promises to employees about their employee welfare provision. This motive to hold cash is more relevant today due to the changing nature of the firm and the increased value it attaches to human capital. A failure on the part of the firm to maintain employee-friendly practices could lead to employee dissatisfaction, a loss of talented human capital and reputation in the labor market and, ultimately, a decline in firm value.

Based on the stakeholder theory, we conjecture that a firm's commitment to investment in employee well-being, as reflected by employee relations ratings, should be associated with a higher level of cash holdings. Using the KLD STATS database, we create an index, the employee welfare index (EWI), to measure the extent of a firm's employee- 
friendliness and as a proxy for its investment in employee well-being. We find strong evidence that firms with higher EWI scores hold more cash. This positive relation is robust to a variety of model specifications and endogeneity concerns. We also show that the effect of employee-friendly practices on cash holdings is stronger for human-capital-intensive firms and industries, as well as for firms in highly competitive and high-labor-mobility industries. These findings provide strong support for the stakeholder theory predictions.

Our additional checks highlight that the positive relation between EWI and cash holdings is strongest for economically non-distressed but financially constrained firms, i.e., the type of firms we anticipate to be highly motivated to showcase their commitment to employee well-being and to be able to afford to do so. Overall, our findings suggest that commitment to employee well-being is an important determinant of corporate cash holdings.

\section{Acknowledgements}

The authors are grateful to an anonymous referee and the editor for invaluable comments and suggestions. We would also like to thank Michael Brennan, Susanne Espenlaub, Ning Gao, Arif Khurshed, Maria Marchica, Roberto Mura, Aydin Ozkan, Syed Walid Reza, Xunhua Su, seminar participants at Hull University Business School as well as participants at the 2013 Financial Management Association annual meeting, and the 2013 Financial Management Association European conference for their helpful comments and suggestions on previous versions of the paper. The usual disclaimer applies. 


\section{References}

Acharya, V.V., Almeida, H., Campello, M., 2007. Is cash negative debt? A hedging perspective on corporate financial policies. J. Financ. Intermed. 16, 515-554.

Acharya, V.V., Baghai, R.P., Subramaniam, K.V., 2014. Wrongful discharge laws and innovation. Rev. Financ. Stud. 27, 301-346.

Agrawal, A.K., Matsa, D.A., 2013. Labor unemployment risk and corporate financing decisions. J. Financ. Econ. 108, 449-470.

Almazan, A., de Motta, A., Titman, S., 2012. Debt, labor markets and the creation and destruction of firms. Working Paper, National Bureau of Economic Research.

Almeida, H., Campello, M., Weisbach, M.S., 2004. The cash flow sensitivity of cash. J. Financ. 59, 1777-1804.

Almeida, H., Campello, M., Weisbach, M., 2011. Corporate financial and investment policies when future financing is not frictionless. J. Corp. Financ. 17, 675-693.

Almeida, H., Campello, M., Cunha, I., Weisbach, M., 2014. Corporate liquidity management: a conceptual framework and survey. Annu. Rev. Financ. Econ. 6, 135-162.

Arnold, M., 2014. Managerial cash use, default, and corporate financial policies. J. Corp. Financ. 27, 305-325.

Autor, D. H., Donohue III, J.J., Schwab, S.J., 2006. The costs of wrongful-discharge laws. Rev. Econ. Stat. 88, 211-231.

Bae, K., Kang, J., Wang, J., 2011. Employee treatment and firm leverage: A test of the stakeholder theory of capital structure. J. Financ. Econ. 100, 130-153.

Banerjee, S., Dasgupta, S., Kim, Y., 2008. Buyer-supplier relationships and the stakeholder theory of capital structure. J. Financ. 63, 2507-2552.

Barton, S.L., Hill, N.C., Sundaram, S., 1989. An empirical test of stakeholder theory predictions of capital structure. Financ. Manag. 18, 36-44.

Bates, T., Kahle, K., Stulz, R., 2009. Why do U.S. firms hold so much more cash than they used to? J. Financ. 64, 1985-2021.

Belo, A., Lin, R., 2013. Labor heterogeneity and asset prices: The importance of skilled labor. Working Paper, Ohio State University. 
Berk, J., Stanton, R., Zechner, J., 2010. Human capital, bankruptcy, and capital structure. J. Financ. 65, 891-926.

Bharath, S.T., Shumway, T., 2008. Forecasting default with the Merton distance to default model. Rev. Financ. Stud. 21, 1339-1369.

Bowen, R.M., DuCharme, L., Shores, D., 1995. Stakeholders' implicit claims and accounting method choice. J. Account. Econ. 20, 255-295.

Brown, J., Matsa, D.A., 2013. Boarding a sinking ship? An investigation of job applications to distress firms? Working Paper, Northwestern University \& NBER.

Brown, J.R., Petersen, B.C., 2011. Cash holdings and R\&D smoothing. J. Corp. Financ. 17, 694-709.

Chemmanur, T., Cheng, Y., Zhang, T., 2013. Human capital, capital structure, and employee pay: An empirical analysis. J. Financ. Econ. 110, 478-502.

Cohn, J., Wardlaw, M., 2012. Firm financing and workplace safety. Working Paper, University of Texas-Austin.

Cornell, B., Shapiro, A.C., 1987. Corporate stakeholders and corporate finance. Financ. Manag. 16, 5-14.

Cronqvist, H., Low, A., Nilsson, M., 2009. Persistence in firm policies, firm origin, and corporate culture: Evidence from corporate spin-offs. Working Paper, Claremont McKenna College.

Davydenko, S., 2012. When do firms default? A study of the default boundary. Working Paper, University of Toronto.

Davydenko, S.A., 2013. Insolvency, illiquidity, and the risk of default. Working Paper, University of Toronto.

Davydenko, S., Strebulaev, I.A., Zhao, X., 2012. A market-based study of the costs of default. Rev. Financ. Stud. 25, 2959-2999.

Demiroglu, C., James, C., 2011. The use of bank lines of credit in liquidity management: A review of empirical evidence. J. Bank. Financ. 35, 775-782.

Donangelo, A., 2014. Labor mobility: Implications for asset pricing. J. Financ. 69, 13211346. 
Duchin, R., 2010. Cash holdings and corporate diversification. J. Financ. 65, 955-992.

Edmans, A., 2011. Does the stock market fully value intangibles? Employee satisfaction and equity prices. J. Financ. Econ. 101, 621-640.

Eisfeldt, A., Papanikolaou, D., 2013. Organization Capital and the Cross-section of Expected Returns. J. Financ. 68, 1365-1406.

Ertugrul, M., 2013. Employee-friendly acquirers and acquisition performance. J. Financ. Res. $36,347-370$.

Falato, A., Kadyrzhanova, D., Sim, J.W., 2012. Rising intangible capital, shrinking debt capacity, and the U.S. corporate savings glut. Working Paper, Federal Reserve Board.

Faleye, O., Trahan, E., 2011. Labor-friendly corporate practices: Is what is good for employees good for shareholders? J. Bus. Ethics 101, 1-27.

Flannery, M.J., Rangan, K.P., 2006. Partial adjustment toward target capital structures. J. Financ. Econ. 79, 469-506.

Francis, B., Hasan, I., Wang, H., 2014. Banking deregulation, consolidation, and corporate cash holdings: U.S. evidence. J. Bank. Financ. 41, 45-56.

Frésard, L., 2010. Financial strength and product market behavior: The real effects of corporate cash holdings. J. Financ. 65, 1097-1122.

Han, S., Qiu, J., 2007. Corporate precautionary cash holdings. J. Corp. Financ. 13, 43-57.

Hanka, G., 1998. Debt and the terms of employment. J. Financ. Econ. 48, 245-282.

Harford, J., Klasa, S., Maxwell, W.F., 2014. Refinancing risk and cash holdings. J. Financ. $69,975-1012$.

Haushalter, D., Klasa, S., Maxwell, W.F., 2007. The influence of product market dynamics on a firm's cash holdings and hedging behavior. J. Financ. Econ. 84, 797-825.

Holder, M.E., Langrehr, F.W., Hexter, J.L., 1998. Dividend policy determinants: An investigation of the influences of stakeholder theory. Financ. Manag. 27, 73-82.

Hong, H., Kubik, J.D., Scheinkman, J.A., 2012. Financial constraints on corporate goodness. Working Paper, National Bureau of Economic Research.

Hovakimian, A., Li, G., 2011. Large sample evidence on capital structure and employee wages. Working Paper, Baruch College. 
Itzkowitz, J., 2013. Customers and cash: How relationships affect suppliers' cash holdings. J. Corp. Financ. 19, 159-180.

Jiao, Y., 2010. Stakeholder welfare and firm value. J. Bank. Financ. 34, 2549-2561.

Kale, J., Shahrur, H., 2007. Corporate capital structure and the characteristics of supplier and customer markets. J. Financ. Econ. 83, 321-365.

Kim, C-S., Mauer, D.C., Sherman, A.E., 1998. The determinants of corporate liquidity: Theory and evidence. J. Financ. Quant. Anal. 33, 335-359.

Kim, H., 2012. Labor market size and firm capital structure: Evidence from large plant openings. Working Paper, Cornell University.

Klasa, S., Maxwell, W., Ortiz-Molina, H., 2009. The strategic use of corporate cash holdings in collective bargaining with labor unions. J. Financ. Econ. 92, 421-442.

Kuzmina, O., 2012. Operating flexibility and capital structure: Evidence from a natural experiment. Working Paper, New Economic School.

Lambrecht, B.M., Pawlina, G., 2013. A theory of net debt and transferable human capital. Rev. Financ. 17, 321-368.

Landier, A., Nair, V.B., Wulf, J., 2009. Trade-offs in staying close: Corporate decision making and geographic dispersion. Rev. Financ. Stud. 22, 1119-1148.

Lawler, E.E., 2008. Talent: Making people your competitive advantage. Jossey-Bass, San Francisco.

Liu, Y., Mauer, D.C., Zhang, Y., 2014. Firm CEO inside debt. J. Bank. Financ. 42, 83-100.

Maksimovic, V., Titman, S., 1991. Financial policy and a firm's reputation for product quality. Rev. Financ. Stud. 2, 175-200.

Matsa, D.A., 2010. Capital structure as a strategic variable: Evidence from collective bargaining. J. Financ. 65, 1197-1232.

Ochoa, J., 2013. Labor heterogeneity, volatility and expected equity returns. Working Paper, Duke University.

Opler, T., Pinkowitz, L., Stulz, R., Williamson, R., 1999. The determinants and implications of corporate cash holdings. J. Financ. Econ. 52, 3-46.

Passov, R., 2003. How much cash does your company need? Harv. Bus. Rev. 81, 119-128. 
Rampini, A.A., Viswanathan, S., 2013. Collateral and capital structure. J. Financ. Econ. 109, 466-492.

Schmalz, M.C., 2013. Managing human capital risk. Working Paper, University of Michigan.

Senbet, L.W., Wang, T.Y., 2012. Corporate financial distress and bankruptcy: A survey. Found. Trend. Financ. 5, 243-335.

Shapiro, A., Titman, S., 1986. An integrated approach to corporate risk management. In: Stern, J., Chew, D. (Eds.), The revolution in corporate finance. Basil Blackwell, New York, pp. 331-354.

Sharpe, S.A., 1994. Financial market imperfections, firm leverage, and the cyclicality of employment. Am. Econ. Rev. 84, 1060-1074.

Simintzi, E., Vig, V., Volpin, P., 2015. Labor protection and leverage. Rev. Financ. Stud. 28, $561-591$.

Strebulaev, I.A., Yang, B., 2013. The mystery of zero-leverage firms. J. Financ. Econ. 109, $1-23$.

Telser, L.G, 1980. A theory of self-enforcing agreements. J. Bus. 53, 27-44.

Titman, S., 1984. The effect of capital structure on a firm's liquidation decision. J. Financ. Econ. 13, 137-151.

Titman, S., Wessels, R., 1988. The determinants of capital structure choice. J. Financ. 43, 119.

Tong, Z., 2011. Firm diversification and the value of corporate cash holdings. J. Corp. Financ. 17, 741-758.

Turban, D.B., Greening, D.W., 1997. Corporate social performance and organizational attractiveness to prospective employees. Acad. Manag. J. 40, 658-672.

Verwijmeren, P., Derwall, J., 2010. Employee well-being, firm leverage, and bankruptcy risk.

J. Bank. Financ. 34, 956-964.

Whited, T., Wu, G., 2006. Financial constraints risk. Rev. Financ. Stud. 19, 531-559.

Zingales, L., 2000. In search of new foundations. J. Financ. 55, 1623-1653. 


\section{Table 1. Summary Statistics for the Employee Welfare Index and its Components}

The sample period is 2003-2009. The components of the employee welfare index (EWI) are obtained from the KLD STATS database. KLD assigns a 0/1 rating for each of these categories. To construct the EWI, we sum up the ratings for the five strength categories and subtract the ratings for the five concern categories, creating an index that ranges from -5 to 5 . Higher values of EWI indicate better employee welfare. The dataset consists of 13,752 firm-year observations. See Section 2.1 for a description of the subcategories.

\begin{tabular}{|c|c|c|c|c|c|}
\hline Variable & Mean & Median & Std. Dev. & Min & Max \\
\hline EWI & -0.312 & 0 & 0.855 & -4 & 4 \\
\hline \multicolumn{6}{|l|}{ Strengths: } \\
\hline Union relations strength & 0.019 & 0 & 0.135 & 0 & 1 \\
\hline Cash profit sharing & 0.045 & 0 & 0.208 & 0 & 1 \\
\hline Employee involvement & 0.071 & 0 & 0.257 & 0 & 1 \\
\hline Retirement benefits strength & 0.042 & 0 & 0.201 & 0 & 1 \\
\hline Work/life benefits & 0.052 & 0 & 0.221 & 0 & 1 \\
\hline \multicolumn{6}{|l|}{ Concerns: } \\
\hline Union relations concern & 0.025 & 0 & 0.157 & 0 & 1 \\
\hline Health and safety concern & 0.106 & 0 & 0.308 & 0 & 1 \\
\hline Workforce reductions & 0.058 & 0 & 0.234 & 0 & 1 \\
\hline Retirement benefits concern & 0.295 & 0 & 0.456 & 0 & 1 \\
\hline Other concerns & 0.055 & 0 & 0.229 & 0 & 1 \\
\hline
\end{tabular}




\section{Table 2. Summary Statistics for Cash Holdings and Control Variables}

Panel A reports summary statistics for the dependent and control variables. Panel B reports correlation coefficients for all variables. Cash holdings is the ratio of cash and short-term investments (che) to total assets (at). Cash flow is earnings after interest, dividends, and tax but before depreciation (oibdp - xint - txt -dvc) scaled by the book value of total assets (at). Net working capital is measured as working capital (wcap) minus cash (che) scaled by total assets (at). Capital expenditure is the ratio of capital expenditure (capx) to total assets (at). Leverage is long-term debt (dltt) plus debt in current liabilities (dlc) scaled by total assets (at). Acquisitions is defined as acquisitions (aqc) to total assets (at). The market-to-book value is defined as the book value of assets (at) plus the market value of common equity (prcc f $*$ csho) minus the book value of common equity (ceq) scaled by the book value of assets (at). Size is measured as the logarithm of the firm's book value of assets (at) in 2003 dollars. To measure industry cash flow volatility, we calculate for each firm-year the standard deviation of firm-level cash flow to assets for the previous five years. Industry cash flow volatility is then calculated as the average of the firm cash flow standard deviation over each industry defined by the two-digit SIC code. Asset volatility is calculated as in Bharath and Shumway (2008). R\&D expenditure is the ratio of $R \& D$ expenses (xrd) to net sales (sale), and is set equal to zero when R\&D expenses (xrd) are missing. Dividend dummy is a dummy variable set equal to one in years in which a firm pays common dividends (dvc), and zero otherwise. $* * *$, and $* * *$ denote statistical significance at the $10 \%, 5 \%$, and $1 \%$ levels respectively.

\section{Panel A: Summary Statistics}

\begin{tabular}{lccccc}
\hline Variable & Mean & Median & Std. Dev. & Min & Max \\
\hline $\begin{array}{l}\text { Dependent variable: } \\
\text { Cash holdings }\end{array}$ & 0.211 & 0.126 & 0.222 & 0.001 & 0.943 \\
Control variables: & & & & & \\
Cash flow & 0.057 & 0.079 & 0.142 & -0.963 & 0.318 \\
Net working capital & 0.055 & 0.048 & 0.148 & -0.460 & 0.455 \\
Capital expenditure & 0.053 & 0.033 & 0.060 & 0.001 & 0.420 \\
Leverage & 0.207 & 0.172 & 0.207 & 0.000 & 0.998 \\
Acquisitions & 0.029 & 0.000 & 0.066 & -0.004 & 0.457 \\
Market-to-book value & 3.017 & 2.234 & 3.756 & -17.904 & 24.919 \\
Size & 6.737 & 6.575 & 1.547 & 3.015 & 10.885 \\
Ind. cash flow volatility & 0.036 & 0.034 & 0.018 & 0.004 & 0.093 \\
Asset volatility & 0.118 & 0.102 & 0.066 & 0.019 & 1.012 \\
R\&D expenditure & 0.190 & 0.003 & 0.884 & 0.000 & 10.218 \\
Dividend dummy & 0.368 & 0.000 & 0.482 & 0.000 & 1.000 \\
\hline
\end{tabular}


Table 2 (cont'd)

Panel B: Correlation Matrix

\begin{tabular}{|c|c|c|c|c|c|c|c|c|c|c|c|c|c|}
\hline & Cash Hold. & EWI & $\mathrm{CF}$ & NWC & Capital Exp. & Leverage & Acq. & MTBV & Size & CF.Vol. & AssetVol. & R\&D & Dividend \\
\hline Cash Holdings & 1.000 & & & & & & & & & & & & \\
\hline EWI & $0.072 * * *$ & 1.000 & & & & & & & & & & & \\
\hline Cash Flow & $-0.417 * * *$ & $0.022 * *$ & 1.000 & & & & & & & & & & \\
\hline NWC & $-0.308 * * *$ & $-0.028 * * *$ & $0.247 * * *$ & 1.000 & & & & & & & & & \\
\hline Capital Exp. & $-0.223 * * *$ & -0.007 & $0.133 * * *$ & $-0.114^{* * *}$ & 1.000 & & & & & & & & \\
\hline Leverage & $-0.346^{* * *}$ & $-0.062 * * *$ & $-0.086^{* * *}$ & $-0.162 * * *$ & $0.093 * * *$ & 1.000 & & & & & & & \\
\hline Acquisitions & $-0.153 * * *$ & $0.028 * * *$ & $0.079 * * *$ & 0.003 & $-0.098 * * *$ & $0.079 * * *$ & 1.000 & & & & & & \\
\hline MTBV & $0.216^{* * *}$ & $0.053 * * *$ & -0.001 & $-0.151 * * *$ & -0.012 & $-0.106^{* * *}$ & $-0.015^{*}$ & 1.000 & & & & & \\
\hline Size & $-0.448 * * *$ & 0.012 & $0.271 * * *$ & $-0.066^{* * *}$ & $0.032 * * *$ & $0.295 * * *$ & $0.037 * * *$ & $-0.096 * * *$ & 1.000 & & & & \\
\hline Ind. $C F$ volatility & $0.202 * * *$ & $0.055 * * *$ & $-0.186^{* * *}$ & $-0.188 * * *$ & $0.077 * * *$ & -0.005 & $-0.032 * * *$ & 0.003 & $-0.101 * * *$ & 1.000 & & & \\
\hline Asset volatility & $0.342 * * *$ & $-0.030 * * *$ & $-0.245^{* * *}$ & $-0.087 * * *$ & $-0.061 * * *$ & $-0.102 * * *$ & $-0.093 * * *$ & $0.065 * * *$ & $-0.395 * * *$ & $0.176^{* * *}$ & 1.000 & & \\
\hline R\&D Exp. & $0.419^{* * *}$ & $0.015^{*}$ & $-0.549 * * *$ & $-0.194 * * *$ & $-0.090 * * *$ & $-0.018^{* *}$ & $-0.060 * * *$ & $0.080 * * *$ & $-0.212 * * *$ & $0.116^{* * *}$ & $0.190^{* * *}$ & 1.000 & \\
\hline Dividend & $-0.303 * * *$ & $-0.026^{* * *}$ & $0.136^{* * *}$ & $0.126^{* * *}$ & -0.008 & $0.047 * * *$ & $-0.023 * * *$ & $-0.039 * * *$ & $0.381 * * *$ & $-0.126^{* * *}$ & $-0.348 * * *$ & $-0.148 * * *$ & 1.000 \\
\hline
\end{tabular}




\section{Table 3. Firm Characteristics across Different Employee Welfare Index Scores}

This table reports the average values of the firm characteristics for the full sample and subsamples based on the sign of the employee welfare index (EWI). We also report the significance of the differences in means between firms with positive and negative employee welfare scores. The dependent and control variables are defined in Table 2 . Sample period is $2003-2009$. $\mathrm{N}$ denotes the number of observations. ${ }^{* * *}$ denote statistical significance at the $1 \%$ level.

\begin{tabular}{|c|c|c|c|c|c|}
\hline & $\begin{array}{c}\text { Overall } \\
\text { sample }\end{array}$ & $\begin{array}{c}\text { Sample } \\
\text { firms with } \\
\text { neutral EWI } \\
(\mathrm{N}=7,371)\end{array}$ & $\begin{array}{c}\text { Sample } \\
\text { firms with } \\
\text { positive EWI } \\
(\mathrm{A}) \\
(\mathrm{N}=1,421)\end{array}$ & $\begin{array}{c}\text { Sample } \\
\text { firms with } \\
\text { negative EWI } \\
(\mathrm{B}) \\
(\mathrm{N}=4,960)\end{array}$ & $\begin{array}{c}\text { Difference } \\
\text { in means } \\
\text { (A-B) }\end{array}$ \\
\hline \multicolumn{6}{|l|}{ Dependent variable: } \\
\hline Cash holdings & 0.211 & 0.215 & 0.226 & 0.202 & $0.024 * * *$ \\
\hline \multicolumn{6}{|l|}{ Control variables: } \\
\hline Cash flow & 0.057 & 0.057 & 0.068 & 0.053 & $0.015 * * *$ \\
\hline Net working capital & 0.055 & 0.062 & 0.026 & 0.052 & $-0.026 * * *$ \\
\hline Capital expenditure & 0.053 & 0.054 & 0.051 & 0.052 & -0.001 \\
\hline Leverage & 0.207 & 0.202 & 0.197 & 0.218 & $-0.021 * * *$ \\
\hline Acquisitions & 0.029 & 0.031 & 0.026 & 0.025 & 0.001 \\
\hline Market-to-book value of equity & 3.017 & 3.048 & 3.400 & 2.862 & $0.538 * * *$ \\
\hline Size & 6.737 & 6.522 & 7.599 & 6.808 & $0.791 * * *$ \\
\hline Industry cash flow volatility & 0.036 & 0.036 & 0.040 & 0.035 & $0.005^{* * *}$ \\
\hline R\&D expenditure & 0.190 & 0.184 & 0.225 & 0.191 & 0.034 \\
\hline Dividend dummy & 0.368 & 0.326 & 0.465 & 0.404 & $0.061 * * *$ \\
\hline
\end{tabular}




\section{Table 4. The Relation between Cash Holdings and the Employee Welfare Index}

Models 1, 2 and 6 present the results of panel regressions in which we regress cash holdings on a set of control variables and the employee welfare index (EWI). All variables are defined as in Table 2. All regressions except Models 3, 4, and 5 include year dummies, but we do not report their coefficient estimates. Models 3 and 4 control for across-firm and across-industry effects. Model 5 presents the results of a Fama-MacBeth regression. Model 6 excludes firms with neutral EWI scores. The p-values in parentheses are based on robust standard errors, clustered at the firm level except in Models 3, 4, and 5.*,**, and *** denote statistical significance at the $10 \%, 5 \%$, and $1 \%$ levels.

\begin{tabular}{|c|c|c|c|c|c|c|}
\hline \multirow[b]{2}{*}{ Variables } & \multicolumn{2}{|c|}{ OLS } & \multirow{2}{*}{$\begin{array}{l}\text { Across } \\
\text { firm } \\
(3)\end{array}$} & \multirow{2}{*}{$\begin{array}{l}\text { Across } \\
\text { industry } \\
(4)\end{array}$} & \multirow{2}{*}{$\begin{array}{c}\text { Fama } \\
\text { MacBeth } \\
\text { (5) }\end{array}$} & \multirow{2}{*}{$\begin{array}{c}+/- \text { score } \\
\text { (6) }\end{array}$} \\
\hline & (1) & (2) & & & & \\
\hline EWI & & $\begin{array}{l}0.010 * * * \\
(0.00)\end{array}$ & $\begin{array}{l}0.012 * * * \\
(0.00)\end{array}$ & $\begin{array}{l}0.013 * * \\
(0.03)\end{array}$ & $\begin{array}{l}0.012 * * * \\
(0.00)\end{array}$ & $\begin{array}{l}0.013 * * * \\
(0.00)\end{array}$ \\
\hline Cash flow & $\begin{array}{l}-0.200^{* * *} \\
(0.00)\end{array}$ & $\begin{array}{l}-0.202^{* * *} \\
(0.00)\end{array}$ & $\begin{array}{l}-0.194 * * * \\
(0.00)\end{array}$ & $\begin{array}{l}-0.084 \\
(0.25)\end{array}$ & $\begin{array}{l}-0.201^{* * *} \\
(0.00)\end{array}$ & $\begin{array}{l}0.017 * * * \\
(0.00)\end{array}$ \\
\hline Net working capital & $\begin{array}{l}-0.419^{* * *} \\
(0.00)\end{array}$ & $\begin{array}{l}-0.418^{* * *} \\
(0.00)\end{array}$ & $\begin{array}{l}-0.444 * * * \\
(0.00)\end{array}$ & $\begin{array}{l}-0.282 * * * \\
(0.00)\end{array}$ & $\begin{array}{l}-0.402 * * * \\
(0.00)\end{array}$ & $\begin{array}{l}-0.013 * * * \\
(0.00)\end{array}$ \\
\hline Capital expenditure & $\begin{array}{l}-0.794 * * * \\
(0.00)\end{array}$ & $\begin{array}{l}-0.795^{* * *} \\
(0.00)\end{array}$ & $\begin{array}{l}-0.904 * * * \\
(0.00)\end{array}$ & $\begin{array}{l}-0.541^{* * *} \\
(0.00)\end{array}$ & $\begin{array}{l}-0.783^{* * *} \\
(0.00)\end{array}$ & $\begin{array}{l}-0.212 * * * \\
(0.00)\end{array}$ \\
\hline Leverage & $\begin{array}{l}-0.285^{* * * *} \\
(0.00)\end{array}$ & $\begin{array}{l}-0.282 * * * \\
(0.00)\end{array}$ & $\begin{array}{l}-0.313^{* * *} \\
(0.00)\end{array}$ & $\begin{array}{l}-0.287 * * * \\
(0.00)\end{array}$ & $\begin{array}{l}-0.290 * * * \\
(0.00)\end{array}$ & $\begin{array}{l}-0.055^{* * *} \\
(0.00)\end{array}$ \\
\hline Acquisitions & $\begin{array}{l}-0.419^{* * *} \\
(0.00)\end{array}$ & $\begin{array}{l}-0.424 * * * \\
(0.00)\end{array}$ & $\begin{array}{l}-0.680 * * * \\
(0.00)\end{array}$ & $\begin{array}{l}-0.629^{* * *} \\
(0.00)\end{array}$ & $\begin{array}{l}-0.406 * * * \\
(0.00)\end{array}$ & $\begin{array}{l}-0.224 * * * \\
(0.00)\end{array}$ \\
\hline Market-to-book & $\begin{array}{l}0.005 * * * \\
(0.00)\end{array}$ & $\begin{array}{l}0.005 * * * \\
(0.00)\end{array}$ & $\begin{array}{l}0.007 * * * \\
(0.00)\end{array}$ & $\begin{array}{l}0.006 * * * \\
(0.00)\end{array}$ & $\begin{array}{l}0.004 * * * \\
(0.00)\end{array}$ & $\begin{array}{l}0.005 * * * \\
(0.00)\end{array}$ \\
\hline Size & $\begin{array}{l}-0.035^{* * *} \\
(0.00)\end{array}$ & $\begin{array}{l}-0.035^{* * *} \\
(0.00)\end{array}$ & $\begin{array}{l}-0.032 * * * \\
(0.00)\end{array}$ & $\begin{array}{l}-0.026^{* * *} \\
(0.00)\end{array}$ & $\begin{array}{l}-0.033^{* * *} \\
(0.00)\end{array}$ & $\begin{array}{l}-0.005 * * \\
(0.02)\end{array}$ \\
\hline Ind. CF volatility & $\begin{array}{l}1.555^{* * *} \\
(0.00)\end{array}$ & $\begin{array}{l}1.508 * * * \\
(0.00)\end{array}$ & $\begin{array}{l}1.184 * * * \\
(0.00)\end{array}$ & $\begin{array}{l}1.033^{* * *} \\
(0.00)\end{array}$ & $\begin{array}{l}1.780 * * * \\
(0.00)\end{array}$ & $\begin{array}{l}0.000 \\
(0.99)\end{array}$ \\
\hline R\&D expenditure & $\begin{array}{l}0.045 * * * \\
(0.00)\end{array}$ & $\begin{array}{l}0.044 * * * \\
(0.00)\end{array}$ & $\begin{array}{l}0.044 * * * \\
(0.00)\end{array}$ & $\begin{array}{l}0.132 * * * \\
(0.10)\end{array}$ & $\begin{array}{l}0.047 * * * \\
(0.00)\end{array}$ & $\begin{array}{l}0.006 * * * \\
(0.00)\end{array}$ \\
\hline Dividend dummy & $\begin{array}{l}-0.050^{* * *} \\
(0.00)\end{array}$ & $\begin{array}{l}-0.050^{* * *} \\
(0.00)\end{array}$ & $\begin{array}{l}-0.055^{* * *} \\
(0.00)\end{array}$ & $\begin{array}{l}-0.051^{* * *} \\
(0.00)\end{array}$ & $\begin{array}{l}-0.045^{* * *} \\
(0.00)\end{array}$ & $\begin{array}{l}0.011 * * * \\
(0.00)\end{array}$ \\
\hline Intercept & $\begin{array}{l}0.525 * * * \\
(0.00)\end{array}$ & $\begin{array}{l}0.531 * * * \\
(0.00)\end{array}$ & $\begin{array}{l}0.537 * * * \\
(0.00)\end{array}$ & $\begin{array}{l}0.434 * * * \\
(0.00)\end{array}$ & $\begin{array}{l}0.516 * * * \\
(0.00)\end{array}$ & $\begin{array}{l}0.203 * * * \\
(0.00)\end{array}$ \\
\hline Year dummies & Yes & Yes & No & No & No & Yes \\
\hline Observations & 10,969 & 10,969 & 2,750 & 584 & 5,069 & 68,057 \\
\hline Adjusted $\mathrm{R}^{2}$ & 0.56 & 0.56 & 0.62 & 0.52 & 0.59 & 0.22 \\
\hline
\end{tabular}




\section{Table 5. Human Capital Intensity, Industry Competition, and Labor Mobility}

This table presents the results of OLS regressions for subsamples based on human capital intensity, intensity of industry competition, and labor mobility. All variables are defined as in Table 2. We measure the human capital intensity of firms using the ratio of R\&D expenditure to total sales. Each year, we define firms with above (below)-median R\&D expenditure to total sales as high (low)-human-capital-intensive. Using two- and threedigit SIC codes, we define human-capital-intensive industries to include all subcategories of the telecommunications, high-tech and healthcare industries. We define competitive industries as those with a Herfindahl-Hirschman Index score below 1,000 and concentrated industries as those with a score above 1,800. To examine the impact of labor mobility on the relation between EWI and cash, we focus on a sample of firms relying on skilled workers. For each year, we define firms with high shares of skilled labor as those in the top $30^{\text {th }}$ percentile of Labor_Skill (Ochoa, 2013; Belo and Lin, 2013). Within the subsample of skill-dependent firms, we further define, for each year, firms with labor mobility (Donangelo, 2014) in the top (bottom) $30^{\text {th }}$ percentile as belonging to high (low)-mobility industries. All models include year dummies but the coefficients are not reported. The last row shows the p-values for the test of differences in the coefficient estimates of EWI between the two subsamples for each split. The p-values in parentheses are based on robust standard errors clustered at the firm level. *,**, and $* * *$ denote statistical significance at the $10 \%, 5 \%$, and $1 \%$ levels, respectively.

\begin{tabular}{|c|c|c|c|c|c|c|c|c|}
\hline \multirow[b]{2}{*}{ Variables } & \multicolumn{2}{|c|}{$\begin{array}{l}\text { Human capital } \\
\text { intensive firms }\end{array}$} & \multicolumn{2}{|c|}{$\begin{array}{c}\text { Human capital } \\
\text { intensive industries }\end{array}$} & \multicolumn{2}{|c|}{$\begin{array}{l}\text { Intensity of } \\
\text { competition }\end{array}$} & \multicolumn{2}{|c|}{ Labor mobility } \\
\hline & $\begin{array}{l}\text { High } \\
\text { (1) }\end{array}$ & $\begin{array}{l}\text { Low } \\
(2)\end{array}$ & $\begin{array}{l}\text { High } \\
(3)\end{array}$ & $\begin{array}{c}\text { Low } \\
(4)\end{array}$ & $\begin{array}{l}\text { High } \\
(5)\end{array}$ & $\begin{array}{c}\text { Low } \\
(6)\end{array}$ & $\begin{array}{l}\text { High } \\
(7)\end{array}$ & $\begin{array}{c}\text { Low } \\
(8)\end{array}$ \\
\hline EWI & $\begin{array}{l}0.013 * * * \\
(0.00)\end{array}$ & $\begin{array}{l}0.003 \\
(0.38)\end{array}$ & $\begin{array}{l}0.019 * * * \\
(0.00)\end{array}$ & $\begin{array}{l}0.005 * \\
(0.06)\end{array}$ & $\begin{array}{l}0.015 * * * \\
(0.00)\end{array}$ & $\begin{array}{l}0.004 \\
(0.32)\end{array}$ & $\begin{array}{l}0.018 * * \\
(0.04)\end{array}$ & $\begin{array}{l}-0.002 \\
(0.76)\end{array}$ \\
\hline Cash flow & $\begin{array}{l}-0.109^{* * *} \\
(0.00)\end{array}$ & $\begin{array}{l}-0.287 * * * \\
(0.00)\end{array}$ & $\begin{array}{l}-0.147^{* * *} \\
(0.00)\end{array}$ & $\begin{array}{l}-0.102^{* * *} \\
(0.00)\end{array}$ & $\begin{array}{l}-0.192^{* * *} \\
(0.00)\end{array}$ & $\begin{array}{l}-0.124^{* *} \\
(0.02)\end{array}$ & $\begin{array}{l}-0.069 \\
(0.29)\end{array}$ & $\begin{array}{l}-0.111 \\
(0.24)\end{array}$ \\
\hline Net working capital & $\begin{array}{l}-0.495^{* * *} \\
(0.00)\end{array}$ & $\begin{array}{l}-0.317 * * * \\
(0.00)\end{array}$ & $\begin{array}{l}-0.577^{* * *} \\
(0.00)\end{array}$ & $\begin{array}{l}-0.362^{* * *} \\
(0.00)\end{array}$ & $\begin{array}{l}-0.405^{* * *} \\
(0.00)\end{array}$ & $\begin{array}{l}-0.407^{* * * *} \\
(0.00)\end{array}$ & $\begin{array}{l}-0.520 * * * \\
(0.00)\end{array}$ & $\begin{array}{l}-0.343 * * * \\
(0.00)\end{array}$ \\
\hline Capital expenditure & $\begin{array}{l}-0.960 * * * \\
(0.00)\end{array}$ & $\begin{array}{l}-0.448^{* * *} \\
(0.00)\end{array}$ & $\begin{array}{l}-1.078^{* * * *} \\
(0.00)\end{array}$ & $\begin{array}{l}-0.593^{* * *} \\
(0.00)\end{array}$ & $\begin{array}{l}-0.827^{* * *} \\
(0.00)\end{array}$ & $\begin{array}{l}-0.467 * * * \\
(0.00)\end{array}$ & $\begin{array}{l}-0.807 * * * \\
(0.00)\end{array}$ & $\begin{array}{l}-0.382 * * * \\
(0.00)\end{array}$ \\
\hline Leverage & $\begin{array}{l}-0.250^{* * *} \\
(0.00)\end{array}$ & $\begin{array}{l}-0.242 * * * \\
(0.00)\end{array}$ & $\begin{array}{l}-0.274^{* * *} \\
(0.00)\end{array}$ & $\begin{array}{l}-0.291^{* * *} \\
(0.00)\end{array}$ & $\begin{array}{l}-0.272^{* * *} \\
(0.00)\end{array}$ & $\begin{array}{l}-0.351^{* * * *} \\
(0.00)\end{array}$ & $\begin{array}{l}-0.240^{* * *} \\
(0.00)\end{array}$ & $\begin{array}{l}-0.209 * * * \\
(0.00)\end{array}$ \\
\hline Acquisitions & $\begin{array}{l}-0.538^{* * *} \\
(0.00)\end{array}$ & $\begin{array}{l}-0.294 * * * \\
(0.00)\end{array}$ & $\begin{array}{l}-0.597^{* * * *} \\
(0.00)\end{array}$ & $\begin{array}{l}-0.300^{* * *} \\
(0.00)\end{array}$ & $\begin{array}{l}-0.434^{* * *} \\
(0.00)\end{array}$ & $\begin{array}{l}-0.305^{* * * *} \\
(0.00)\end{array}$ & $\begin{array}{l}-0.470^{* * *} \\
(0.00)\end{array}$ & $\begin{array}{l}-0.276^{* * * *} \\
(0.00)\end{array}$ \\
\hline Market-to-book & $\begin{array}{l}0.004 * * * \\
(0.00)\end{array}$ & $\begin{array}{l}0.004 * * * \\
(0.00)\end{array}$ & $\begin{array}{l}0.006 * * * \\
(0.00)\end{array}$ & $\begin{array}{l}0.004 * * * \\
(0.00)\end{array}$ & $\begin{array}{l}0.006^{* * * *} \\
(0.00)\end{array}$ & $\begin{array}{l}0.005^{* * * *} \\
(0.00)\end{array}$ & $\begin{array}{l}0.004 \\
(0.11)\end{array}$ & $\begin{array}{l}0.010^{* * * *} \\
(0.00)\end{array}$ \\
\hline Size & $\begin{array}{l}-0.039 * * * \\
(0.00)\end{array}$ & $\begin{array}{l}-0.029 * * * \\
(0.00)\end{array}$ & $\begin{array}{l}-0.047^{* * * *} \\
(0.00)\end{array}$ & $\begin{array}{l}-0.028^{* * *} \\
(0.00)\end{array}$ & $\begin{array}{l}-0.032^{* * *} \\
(0.00)\end{array}$ & $\begin{array}{l}-0.029 * * * \\
(0.00)\end{array}$ & $\begin{array}{l}-0.042^{* * * *} \\
(0.00)\end{array}$ & $\begin{array}{l}-0.035^{* * *} \\
(0.00)\end{array}$ \\
\hline Ind. CF volatility & $\begin{array}{l}1.463 * * * \\
(0.00)\end{array}$ & $\begin{array}{l}0.654 * * * \\
(0.00)\end{array}$ & $\begin{array}{l}1.401 * * * \\
(0.00)\end{array}$ & $\begin{array}{l}0.919 * * * \\
(0.00)\end{array}$ & $\begin{array}{l}1.450 * * * \\
(0.00)\end{array}$ & $\begin{array}{l}1.385^{* * * *} \\
(0.00)\end{array}$ & $\begin{array}{l}2.435 * * * \\
(0.00)\end{array}$ & $\begin{array}{l}-0.279 \\
(0.54)\end{array}$ \\
\hline R\&D expenditure & $\begin{array}{l}0.039 * * * \\
(0.00)\end{array}$ & $\begin{array}{l}-0.827 \\
(0.71)\end{array}$ & $\begin{array}{l}0.027 * * * \\
(0.00)\end{array}$ & $\begin{array}{l}0.089 * * * \\
(0.00)\end{array}$ & $\begin{array}{l}0.044 * * * \\
(0.00)\end{array}$ & $\begin{array}{l}0.096^{* * * *} \\
(0.00)\end{array}$ & $\begin{array}{l}0.061 \\
(0.27)\end{array}$ & $\begin{array}{l}0.046^{* * * *} \\
(0.00)\end{array}$ \\
\hline Dividend dummy & $\begin{array}{l}-0.089 * * * \\
(0.00)\end{array}$ & $\begin{array}{l}-0.007 \\
(0.23)\end{array}$ & $\begin{array}{l}-0.060^{* * * *} \\
(0.00)\end{array}$ & $\begin{array}{l}-0.032^{* * *} \\
(0.00)\end{array}$ & $\begin{array}{l}-0.052^{* * *} \\
(0.00)\end{array}$ & $\begin{array}{l}-0.042 * * * \\
(0.00)\end{array}$ & $\begin{array}{l}-0.058^{* * *} \\
(0.00)\end{array}$ & $\begin{array}{l}-0.027^{*} \\
(0.08)\end{array}$ \\
\hline Intercept & $\begin{array}{l}0.630 * * * \\
(0.00)\end{array}$ & $\begin{array}{l}0.432 * * * \\
(0.00)\end{array}$ & $\begin{array}{l}0.686^{* * * *} \\
(0.00)\end{array}$ & $\begin{array}{l}0.463 * * * \\
(0.00)\end{array}$ & $\begin{array}{l}0.523 * * * \\
(0.00)\end{array}$ & $\begin{array}{l}0.477 * * * \\
(0.00)\end{array}$ & $\begin{array}{l}0.592 * * * \\
(0.00)\end{array}$ & $\begin{array}{l}0.485^{* * * *} \\
(0.00)\end{array}$ \\
\hline Year dummies & Yes & Yes & Yes & Yes & Yes & Yes & Yes & Yes \\
\hline Observations & 5,477 & 5,492 & 3,272 & 7,697 & 5,587 & 3,096 & 865 & 868 \\
\hline $\begin{array}{l}\text { Adjusted } \mathrm{R}^{2} \\
\text { p-value }(F \text {-test of } \\
\text { equal coefficient } \\
\text { estimates on EWI) }\end{array}$ & $\begin{array}{l}0.59 \\
(0.04)\end{array}$ & 0.39 & $\begin{array}{l}0.60 \\
(0.02)\end{array}$ & 0.46 & $\begin{array}{l}0.54 \\
(0.03)\end{array}$ & 0.51 & $\begin{array}{l}0.48 \\
(0.08)\end{array}$ & 0.50 \\
\hline
\end{tabular}




\section{Table 6. The Impact of the Employee Welfare Index on Cash Holdings Conditional on Economic Distress and Financial Constraints}

Panel A presents the results of OLS regressions for subsamples based on economic distress. All variables are defined as in Table 2. We measure the degree of economic distress using two different proxies (Davydenko, 2013). The first proxy is the assets-to-debt ratio $\left(\left(\operatorname{at}+\left(\operatorname{prcc} \_f * \operatorname{csho}\right)-c e q\right) /(\operatorname{dltt}+\mathrm{dlc})\right)$. In the models using this proxy, we exclude firms with leverage ratios below 5\% because, based on this proxy, low-leverage firms would most likely be classified as economically non-distressed (see Footnote 19 for more details). As a second proxy, we use the probability of default (Bharath and Shumway, 2008). For each year, we define firms with an above (below)-median value of assets relative to debt and firms with zero (greater than zero) default probabilities as non-distressed (distressed). The last row shows the p-values for the test of differences in the coefficient estimates for EWI between the two subsamples for each split. In Panel B, we report the results of regressions for subsamples based on economic distress and financial constraints. In Models 1-4 (5-8), we measure economic distress using the assets-to-debt ratio (the probability of default). We measure the degree of financial constraint using the Whited and $\mathrm{Wu}(2006)(\mathrm{WW})$ index $(\mathrm{WW}=-0.091 \times$ Cash Flow $-0.062 \times$ Dividend Dummy $+0.021 \times$ Long-Term Debt $-0.044 \times$ Size $+0.102 \times$ Industry Sales Growth $-0.035 \times$ Sales Growth). For each year, we define firms with above (below)-median scores on the WW index as constrained (unconstrained). In Models 1, 2, 5, and 6 (3, 4, 7, and 8), we control for firm risk using industry cash flow volatility (asset volatility). All models include year dummies but the coefficients are not reported. The p-values in parentheses are based on robust standard errors that allow for clustering at the firm level. *, **, and *** denote statistical significance at the $10 \%, 5 \%$, and $1 \%$ levels, respectively. 
Panel A: Economic Distress

\begin{tabular}{|c|c|c|c|c|c|c|c|c|}
\hline \multirow[b]{2}{*}{ Variables } & \multicolumn{4}{|c|}{ Assets-to-Debt Ratio } & \multicolumn{4}{|c|}{ Probability of Default } \\
\hline & $\begin{array}{c}\text { Non-distressed } \\
\text { (1) }\end{array}$ & $\begin{array}{c}\text { Distressed } \\
(2) \\
\end{array}$ & $\begin{array}{c}\text { Non-distressed } \\
(3) \\
\end{array}$ & $\begin{array}{c}\text { Distressed } \\
(4) \\
\end{array}$ & $\begin{array}{c}\text { Non-distressed } \\
(5) \\
\end{array}$ & $\begin{array}{c}\text { Distressed } \\
(6)\end{array}$ & $\begin{array}{c}\text { Non-distressed } \\
(7)\end{array}$ & $\begin{array}{c}\text { Distressed } \\
(8)\end{array}$ \\
\hline Cash flow & $\begin{array}{c}-0.249 * * * \\
(0.00)\end{array}$ & $\begin{array}{c}-0.249 * * * \\
(0.00)\end{array}$ & $\begin{array}{c}-0.199 * * * \\
(0.00)\end{array}$ & $\begin{array}{c}-0.212 * * * \\
(0.00)\end{array}$ & $\begin{array}{c}-0.216^{* * *} \\
(0.00)\end{array}$ & $\begin{array}{c}-0.259 * * * \\
(0.00)\end{array}$ & $\begin{array}{c}-0.187 * * * \\
(0.00)\end{array}$ & $\begin{array}{c}-0.243 * * * \\
(0.00)\end{array}$ \\
\hline Net working capital & $\begin{array}{c}-0.340 * * * \\
(0.00)\end{array}$ & $\begin{array}{c}-0.224 * * * \\
(0.00)\end{array}$ & $\begin{array}{c}-0.330 * * * \\
(0.00)\end{array}$ & $\begin{array}{c}-0.204 * * * \\
(0.00)\end{array}$ & $\begin{array}{c}-0.369 * * * \\
(0.00)\end{array}$ & $\begin{array}{c}-0.317 * * * \\
(0.00)\end{array}$ & $\begin{array}{c}-0.367 * * * \\
(0.00)\end{array}$ & $\begin{array}{c}-0.294 * * * \\
(0.00)\end{array}$ \\
\hline Capital expenditure & $\begin{array}{c}-0.675^{* * * *} \\
(0.00)\end{array}$ & $\begin{array}{c}-0.359 * * * \\
(0.00)\end{array}$ & $\begin{array}{c}-0.707 * * * \\
(0.00)\end{array}$ & $\begin{array}{c}-0.371 * * * \\
(0.00)\end{array}$ & $\begin{array}{c}-0.630 * * * \\
(0.00)\end{array}$ & $\begin{array}{c}-0.563 * * * \\
(0.00)\end{array}$ & $\begin{array}{c}-0.660 * * * \\
(0.00)\end{array}$ & $\begin{array}{c}-0.548 * * * \\
(0.00)\end{array}$ \\
\hline Leverage & $\begin{array}{l}0.001 \\
(0.98)\end{array}$ & $\begin{array}{c}-0.033^{*} \\
(0.06)\end{array}$ & $\begin{array}{l}0.015 \\
(0.73)\end{array}$ & $\begin{array}{l}-0.009 \\
(0.65)\end{array}$ & $\begin{array}{c}-0.209 * * * \\
(0.00)\end{array}$ & $\begin{array}{c}-0.081 * * * \\
(0.00)\end{array}$ & $\begin{array}{c}-0.181 * * * \\
(0.00)\end{array}$ & $\begin{array}{c}-0.048^{* *} \\
(0.05)\end{array}$ \\
\hline Acquisitions & $\begin{array}{c}-0.447 * * * \\
(0.00)\end{array}$ & $\begin{array}{c}-0.182 * * * \\
(0.00)\end{array}$ & $\begin{array}{c}-0.440 * * * \\
(0.00)\end{array}$ & $\begin{array}{c}-0.181 * * * \\
(0.00)\end{array}$ & $\begin{array}{c}-0.362 * * * \\
(0.00)\end{array}$ & $\begin{array}{c}-0.222 * * * \\
(0.00)\end{array}$ & $\begin{array}{c}-0.359 * * * \\
(0.00)\end{array}$ & $\begin{array}{c}-0.198 * * * \\
(0.00)\end{array}$ \\
\hline MTBV & $\begin{array}{c}0.005^{* * *} \\
(0.00)\end{array}$ & $\begin{array}{c}0.003 * * * \\
(0.00)\end{array}$ & $\begin{array}{c}0.005 * * * \\
(0.00)\end{array}$ & $\begin{array}{c}0.002 * * * \\
(0.00)\end{array}$ & $\begin{array}{c}0.006^{* * *} \\
(0.00)\end{array}$ & $\begin{array}{c}0.004 * * * \\
(0.00)\end{array}$ & $\begin{array}{c}0.005^{* * *} \\
(0.00)\end{array}$ & $\begin{array}{c}0.003^{* * *} \\
(0.00)\end{array}$ \\
\hline Ind. CF volatility & $\begin{array}{l}0.009 \\
(0.64)\end{array}$ & $\begin{array}{l}0.000 \\
(0.90)\end{array}$ & & & $\begin{array}{l}0.011 \\
(0.34)\end{array}$ & $\begin{array}{l}-0.005 \\
(0.48)\end{array}$ & & \\
\hline Asset volatility & & & $\begin{array}{c}0.302 * * * \\
(0.00)\end{array}$ & $\begin{array}{c}0.411 * * * \\
(0.00)\end{array}$ & & & $\begin{array}{c}0.613 * * * \\
(0.00)\end{array}$ & $\begin{array}{c}0.356^{* * *} \\
(0.00)\end{array}$ \\
\hline R\&D expenditure & $\begin{array}{c}0.045^{* * *} \\
(0.00)\end{array}$ & $\begin{array}{c}0.069 * * * \\
(0.00)\end{array}$ & $\begin{array}{c}0.053 * * * \\
(0.00)\end{array}$ & $\begin{array}{c}0.069^{* * *} \\
(0.00)\end{array}$ & $\begin{array}{c}0.056^{* * *} \\
(0.00)\end{array}$ & $\begin{array}{c}0.062 * * * \\
(0.00)\end{array}$ & $\begin{array}{c}0.054 * * * \\
(0.00)\end{array}$ & $\begin{array}{c}0.061 * * * \\
(0.00)\end{array}$ \\
\hline Dividend dummy & $\begin{array}{c}-0.058^{* * * *} \\
(0.00)\end{array}$ & $\begin{array}{c}-0.032 * * * \\
(0.00)\end{array}$ & $\begin{array}{c}-0.050^{* * * *} \\
(0.00)\end{array}$ & $\begin{array}{c}-0.022 * * * \\
(0.00)\end{array}$ & $\begin{array}{c}-0.051 * * * \\
(0.00)\end{array}$ & $\begin{array}{c}-0.043 * * * \\
(0.00)\end{array}$ & $\begin{array}{c}-0.037 * * * \\
(0.00)\end{array}$ & $\begin{array}{c}-0.036^{* * *} \\
(0.00)\end{array}$ \\
\hline Intercept & $\begin{array}{c}0.379 * * * \\
(0.00)\end{array}$ & $\begin{array}{c}0.295 * * * \\
(0.00)\end{array}$ & $\begin{array}{c}0.300 * * * \\
(0.00)\end{array}$ & $\begin{array}{c}0.196 * * * \\
(0.00)\end{array}$ & $\begin{array}{c}0.465 * * * \\
(0.00)\end{array}$ & $\begin{array}{c}0.406 * * * \\
(0.00)\end{array}$ & $\begin{array}{c}0.343 * * * \\
(0.00)\end{array}$ & $\begin{array}{c}0.254 * * * \\
(0.00)\end{array}$ \\
\hline Year dummies & Yes & Yes & Yes & Yes & Yes & Yes & Yes & Yes \\
\hline Observations & 3,889 & 3,891 & 3,411 & 3,416 & 6,230 & 1,886 & 6,239 & 1,888 \\
\hline $\begin{array}{l}\text { Adjusted } \mathrm{R}^{2} \\
\mathrm{p} \text {-value (F-test of equal } \\
\text { coefficients on EWI) }\end{array}$ & $\begin{array}{c}0.51 \\
(0.03)\end{array}$ & 0.41 & $\begin{array}{c}0.51 \\
(0.06)\end{array}$ & 0.43 & $\begin{array}{c}0.50 \\
(0.04)\end{array}$ & 0.50 & $\begin{array}{c}0.52 \\
(0.03)\end{array}$ & 0.52 \\
\hline
\end{tabular}


Panel B: Economic Distress and Financial Constraints

\begin{tabular}{|c|c|c|c|c|c|c|c|c|}
\hline \multirow[b]{2}{*}{ Variables } & \multicolumn{3}{|c|}{ Assets-to-Debt Ratio } & \multicolumn{5}{|c|}{ Probability of Default } \\
\hline & $\begin{array}{c}\text { Non-distressed } \\
\& \\
\text { Constrained } \\
(1) \\
\end{array}$ & $\begin{array}{c}\text { Non-distressed } \\
\& \\
\text { Unconstrained } \\
(2) \\
\end{array}$ & $\begin{array}{c}\text { Non-distressed } \\
\& \\
\text { Constrained } \\
(3) \\
\end{array}$ & $\begin{array}{c}\text { Non-distressed } \\
\& \\
\text { Unconstrained } \\
(4) \\
\end{array}$ & $\begin{array}{c}\text { Non-distressed } \\
\& \\
\text { Constrained } \\
(5) \\
\end{array}$ & $\begin{array}{c}\text { Non-distressed } \\
\& \\
\text { Unconstrained } \\
(6)\end{array}$ & $\begin{array}{c}\text { Non-distressed } \\
\& \\
\text { Constrained } \\
(7) \\
\end{array}$ & $\begin{array}{c}\text { Non-distressed } \\
\& \\
\text { Unconstrained } \\
(8) \\
\end{array}$ \\
\hline EWI & $\begin{array}{c}0.014^{* *} \\
(0.04)\end{array}$ & $\begin{array}{l}0.005 \\
(0.13)\end{array}$ & $\begin{array}{c}0.017 * * \\
(0.01)\end{array}$ & $\begin{array}{l}0.004 \\
(0.20)\end{array}$ & $\begin{array}{c}0.015^{* *} \\
(0.01)\end{array}$ & $\begin{array}{c}0.007 * * \\
(0.01)\end{array}$ & $\begin{array}{c}0.017 * * * \\
(0.00)\end{array}$ & $\begin{array}{c}0.007 * * \\
(0.01)\end{array}$ \\
\hline Cash flow & $\begin{array}{c}-0.167 * * * \\
(0.00)\end{array}$ & $\begin{array}{l}0.153 \\
(0.14)\end{array}$ & $\begin{array}{c}-0.187 * * * \\
(0.00)\end{array}$ & $\begin{array}{l}-0.171 \\
(0.11)\end{array}$ & $\begin{array}{c}-0.236^{* * * *} \\
(0.00)\end{array}$ & $\begin{array}{c}0.152^{*} \\
(0.05)\end{array}$ & $\begin{array}{c}-0.204^{* * * *} \\
(0.00)\end{array}$ & $\begin{array}{c}0.158 * * \\
(0.04)\end{array}$ \\
\hline Net working capital & $\begin{array}{c}-0.295^{* * *} \\
(0.00)\end{array}$ & $\begin{array}{c}-0.175 * * * \\
(0.00)\end{array}$ & $\begin{array}{c}-0.284 * * * \\
(0.00)\end{array}$ & $\begin{array}{c}-0.194 * * * \\
(0.00)\end{array}$ & $\begin{array}{c}-0.328 * * * \\
(0.00)\end{array}$ & $\begin{array}{c}-0.190 * * * \\
(0.00)\end{array}$ & $\begin{array}{c}-0.327 * * * \\
(0.00)\end{array}$ & $\begin{array}{c}-0.200 * * * \\
(0.00)\end{array}$ \\
\hline Capital expenditure & $\begin{array}{c}-0.744 * * * \\
(0.00)\end{array}$ & $\begin{array}{c}-0.440 * * * \\
(0.00)\end{array}$ & $\begin{array}{c}-0.693 * * * \\
(0.00)\end{array}$ & $\begin{array}{c}-0.502 * * * \\
(0.00)\end{array}$ & $\begin{array}{c}-0.654 * * * \\
(0.00)\end{array}$ & $\begin{array}{c}-0.385^{* * * *} \\
(0.00)\end{array}$ & $\begin{array}{c}-0.670 * * * \\
(0.00)\end{array}$ & $\begin{array}{c}-0.448 * * * \\
(0.00)\end{array}$ \\
\hline Leverage & $\begin{array}{l}0.085 \\
(0.19)\end{array}$ & $\begin{array}{c}-0.141^{* *} \\
(0.04)\end{array}$ & $\begin{array}{l}0.081 \\
(0.25)\end{array}$ & $\begin{array}{l}-0.110 \\
(0.11)\end{array}$ & $\begin{array}{c}-0.147 * * * \\
(0.00)\end{array}$ & $\begin{array}{c}-0.163^{* * * *} \\
(0.00)\end{array}$ & $\begin{array}{c}-0.125^{* * * *} \\
(0.00)\end{array}$ & $\begin{array}{c}-0.135^{* * * *} \\
(0.00)\end{array}$ \\
\hline Acquisitions & $\begin{array}{c}-0.435^{* * *} \\
(0.00)\end{array}$ & $\begin{array}{c}-0.312 * * * \\
(0.00)\end{array}$ & $\begin{array}{c}-0.409 * * * \\
(0.00)\end{array}$ & $\begin{array}{c}-0.318^{* * *} \\
(0.00)\end{array}$ & $\begin{array}{c}-0.403 * * * \\
(0.00)\end{array}$ & $\begin{array}{c}-0.259 * * * \\
(0.00)\end{array}$ & $\begin{array}{c}-0.385^{* * *} \\
(0.00)\end{array}$ & $\begin{array}{c}-0.270^{* * *} \\
(0.00)\end{array}$ \\
\hline MTBV & $\begin{array}{c}0.007 * * * \\
(0.00)\end{array}$ & $\begin{array}{l}0.000 \\
(0.83)\end{array}$ & $\begin{array}{c}0.008 * * * \\
(0.00)\end{array}$ & $\begin{array}{l}0.001 \\
(0.72)\end{array}$ & $\begin{array}{c}0.008 * * * \\
(0.00)\end{array}$ & $\begin{array}{l}0.001 \\
(0.50)\end{array}$ & $\begin{array}{c}0.007 * * * \\
(0.00)\end{array}$ & $\begin{array}{l}0.001 \\
(0.38)\end{array}$ \\
\hline Size & $\begin{array}{c}-0.022 * * * * \\
(0.00)\end{array}$ & $\begin{array}{c}-0.014 * * * \\
(0.00)\end{array}$ & $\begin{array}{c}-0.018^{* *} \\
(0.02)\end{array}$ & $\begin{array}{c}-0.011 * * * * \\
(0.00)\end{array}$ & $\begin{array}{c}-0.037 * * * \\
(0.00)\end{array}$ & $\begin{array}{c}-0.016^{* * * *} \\
(0.00)\end{array}$ & $\begin{array}{c}-0.031^{* * * *} \\
(0.00)\end{array}$ & $\begin{array}{c}-0.012 * * * \\
(0.00)\end{array}$ \\
\hline Ind. CF volatility & $\begin{array}{l}0.028 \\
(0.23)\end{array}$ & $\begin{array}{l}0.071 \\
(0.17)\end{array}$ & & & $\begin{array}{l}0.014 \\
(0.31)\end{array}$ & $\begin{array}{c}0.016 * * \\
(0.03)\end{array}$ & & \\
\hline Asset volatility & & & $\begin{array}{c}0.274^{*} \\
(0.06)\end{array}$ & $\begin{array}{c}0.438 * * * \\
(0.00)\end{array}$ & & & $\begin{array}{c}0.696^{* * *} \\
(0.00)\end{array}$ & $\begin{array}{c}0.628^{* * *} \\
(0.00)\end{array}$ \\
\hline R\&D expenditure & $\begin{array}{c}0.054 * * * \\
(0.00)\end{array}$ & $\begin{array}{c}0.739 * * * \\
(0.00)\end{array}$ & $\begin{array}{c}0.048 * * * \\
(0.00)\end{array}$ & $\begin{array}{c}0.771 * * * \\
(0.00)\end{array}$ & $\begin{array}{c}0.049 * * * \\
(0.00)\end{array}$ & $\begin{array}{c}0.671 * * * \\
(0.00)\end{array}$ & $\begin{array}{c}0.049 * * * \\
(0.00)\end{array}$ & $\begin{array}{c}0.660 * * * \\
(0.00)\end{array}$ \\
\hline Dividend dummy & $\begin{array}{c}-0.074 * * * \\
(0.00)\end{array}$ & $\begin{array}{l}-0.019 \\
(0.12)\end{array}$ & $\begin{array}{c}-0.066^{* * * *} \\
(0.00)\end{array}$ & $\begin{array}{l}-0.009 \\
(0.48)\end{array}$ & $\begin{array}{c}-0.084 * * * \\
(0.00)\end{array}$ & $\begin{array}{c}-0.017 * \\
(0.07)\end{array}$ & $\begin{array}{c}-0.067 * * * \\
(0.00)\end{array}$ & $\begin{array}{l}-0.007 \\
(0.46)\end{array}$ \\
\hline Intercept & $\begin{array}{c}0.385 * * * \\
(0.00)\end{array}$ & $\begin{array}{c}0.266^{* * *} \\
(0.00)\end{array}$ & $\begin{array}{c}0.322 * * * \\
(0.00)\end{array}$ & $\begin{array}{c}0.201^{* * *} \\
(0.00)\end{array}$ & $\begin{array}{c}0.540 * * * \\
(0.00)\end{array}$ & $\begin{array}{c}0.293 * * * \\
(0.00)\end{array}$ & $\begin{array}{c}0.421 * * * \\
(0.00)\end{array}$ & $\begin{array}{c}0.220^{* * *} \\
(0.00)\end{array}$ \\
\hline Year dummies & Yes & Yes & Yes & Yes & Yes & Yes & Yes & Yes \\
\hline Observations & 1,078 & 1,135 & 1,010 & 1,046 & 1,729 & 1,929 & 1,730 & 1,929 \\
\hline Adjusted $\mathrm{R}^{2}$ & 0.46 & 0.38 & 0.47 & 0.41 & 0.46 & 0.40 & 0.47 & 0.42 \\
\hline
\end{tabular}




\section{Table 7. Cash Holdings and Employee Welfare Index: Instrumental Variable Regressions}

This table presents the results of two-stage least squares regressions. The employee welfare index (EWI) is the endogenous variable. The dependent and explanatory variables are defined as in Table 2 . In the first-stage regression, we regress EWI on the control and instrumental variables. In the second-stage regression, we regress cash holdings on the predicted EWI together with other determinants of cash holdings. All regressions include year dummies but we do not report their coefficient estimates. Pension and retirement expenses per worker t $10_{0}$ is the natural log of 10-year-lagged pension and retirement expenses per worker. Industry wage is measured as total labor and related expenses divided by total employees across firms in the same industry. The $p$-values in parentheses are based on robust standard errors clustered at the firm level. *,**, and *** denote statistical significance at the $10 \%, 5 \%$, and $1 \%$ levels, respectively.

\begin{tabular}{|c|c|c|c|c|c|c|}
\hline & \multicolumn{2}{|c|}{ (1) } & \multicolumn{2}{|c|}{ (2) } & \multicolumn{2}{|c|}{ (3) } \\
\hline $\begin{array}{l}\text { Variables } \\
\text { Dependent }\end{array}$ & $\begin{array}{l}\text { First } \\
\text { stage } \\
(\mathrm{EWI}) \\
\end{array}$ & $\begin{array}{c}\text { Second } \\
\text { stage } \\
\text { (Cash) }\end{array}$ & $\begin{array}{l}\text { First } \\
\text { stage } \\
(\mathrm{EWI}) \\
\end{array}$ & $\begin{array}{c}\text { Second } \\
\text { stage } \\
\text { (Cash) }\end{array}$ & $\begin{array}{l}\text { First } \\
\text { stage } \\
(\mathrm{EWI}) \\
\end{array}$ & $\begin{array}{l}\text { Second } \\
\text { stage } \\
\text { (Cash) }\end{array}$ \\
\hline EWI & & $\begin{array}{l}0.053 * * * \\
(0.00)\end{array}$ & & $\begin{array}{l}0.122 * * * \\
(0.00)\end{array}$ & & $\begin{array}{l}0.076^{* * * *} \\
(0.00)\end{array}$ \\
\hline Cash flow & $\begin{array}{l}0.905 * * * \\
(0.00)\end{array}$ & $\begin{array}{l}-0.151 * * * \\
(0.00)\end{array}$ & $\begin{array}{l}0.438^{* * *} \\
(0.00)\end{array}$ & $\begin{array}{l}-0.238 * * * \\
(0.00)\end{array}$ & $\begin{array}{l}0.994 * * * \\
(0.00)\end{array}$ & $\begin{array}{l}-0.216^{* * *} \\
(0.00)\end{array}$ \\
\hline Net working capital & $\begin{array}{l}-0.576^{* * *} \\
(0.00)\end{array}$ & $\begin{array}{l}-0.331 * * * \\
(0.00)\end{array}$ & $\begin{array}{l}-0.542^{* * *} \\
(0.00)\end{array}$ & $\begin{array}{l}-0.328 * * * \\
(0.00)\end{array}$ & $\begin{array}{l}-0.867 * * * \\
(0.00)\end{array}$ & $\begin{array}{l}-0.330 * * * \\
(0.00)\end{array}$ \\
\hline Capital expenditure & $\begin{array}{l}-0.509 \\
(0.21)\end{array}$ & $\begin{array}{l}-0.654 * * * \\
(0.00)\end{array}$ & $\begin{array}{l}0.182 \\
(0.53)\end{array}$ & $\begin{array}{l}-0.818 * * * \\
(0.00)\end{array}$ & $\begin{array}{l}-0.339 \\
(0.43)\end{array}$ & $\begin{array}{l}-0.682 * * * \\
(0.00)\end{array}$ \\
\hline Leverage & $\begin{array}{l}-0.675^{* * *} \\
(0.00)\end{array}$ & $\begin{array}{l}-0.252 * * * \\
(0.00)\end{array}$ & $\begin{array}{l}-0.532 * * * \\
(0.00)\end{array}$ & $\begin{array}{l}-0.195 * * * \\
(0.00)\end{array}$ & $\begin{array}{l}-0.755^{* * *} \\
(0.00)\end{array}$ & $\begin{array}{l}-0.242 * * * \\
(0.00)\end{array}$ \\
\hline Acquisitions & $\begin{array}{l}0.453 * * \\
(0.02)\end{array}$ & $\begin{array}{l}-0.332 * * * \\
(0.00)\end{array}$ & $\begin{array}{l}0.416^{* * *} \\
(0.01)\end{array}$ & $\begin{array}{l}-0.477 * * * \\
(0.00)\end{array}$ & $\begin{array}{l}0.364 * \\
(0.08)\end{array}$ & $\begin{array}{l}-0.367 * * * \\
(0.00)\end{array}$ \\
\hline Market-to-book & $\begin{array}{l}0.020 * * * \\
(0.01)\end{array}$ & $\begin{array}{l}0.004 * * * \\
(0.00)\end{array}$ & $\begin{array}{l}0.017 * * * \\
(0.00)\end{array}$ & $\begin{array}{l}0.003 * * \\
(0.02)\end{array}$ & $\begin{array}{l}0.022 * * * \\
(0.00)\end{array}$ & $\begin{array}{l}0.003 * * \\
(0.02)\end{array}$ \\
\hline Size & $\begin{array}{l}-0.023 \\
(0.29)\end{array}$ & $\begin{array}{l}-0.024 * * * \\
(0.00)\end{array}$ & $\begin{array}{l}0.035^{*} \\
(0.10)\end{array}$ & $\begin{array}{l}-0.033 * * * \\
(0.00)\end{array}$ & $\begin{array}{l}0.006 \\
(0.81)\end{array}$ & $\begin{array}{l}-0.026 * * * \\
(0.00)\end{array}$ \\
\hline Ind. $\mathrm{CF}$ volatility & $\begin{array}{l}3.039 * * \\
(0.04)\end{array}$ & $\begin{array}{l}0.962 * * * \\
(0.00)\end{array}$ & $\begin{array}{l}2.891 * * \\
(0.03)\end{array}$ & $\begin{array}{l}1.155^{* * *} \\
(0.00)\end{array}$ & $\begin{array}{l}2.226 \\
(0.18)\end{array}$ & $\begin{array}{l}1.116^{* * *} \\
(0.00)\end{array}$ \\
\hline R\&D expenditure & $\begin{array}{l}0.214 * * \\
(0.03)\end{array}$ & $\begin{array}{l}0.070 * * * \\
(0.01)\end{array}$ & $\begin{array}{l}0.063^{* * *} \\
(0.01)\end{array}$ & $\begin{array}{l}0.041 \text { *** } \\
(0.00)\end{array}$ & $\begin{array}{l}0.187 * * \\
(0.05)\end{array}$ & $\begin{array}{l}0.056^{* *} \\
(0.04)\end{array}$ \\
\hline Dividend dummy & $\begin{array}{l}-0.092 * \\
(0.06)\end{array}$ & $\begin{array}{l}-0.039 * * * \\
(0.00)\end{array}$ & $\begin{array}{l}-0.047 \\
(0.31)\end{array}$ & $\begin{array}{l}-0.048 * * * \\
(0.00)\end{array}$ & $\begin{array}{l}-0.103^{*} \\
(0.06)\end{array}$ & $\begin{array}{l}-0.046^{* * * *} \\
(0.00)\end{array}$ \\
\hline Intercept & $\begin{array}{l}-0.193 \\
(0.24)\end{array}$ & $\begin{array}{l}0.426 * * * \\
(0.00)\end{array}$ & $\begin{array}{l}-1.720 * * * \\
(0.00)\end{array}$ & $\begin{array}{l}0.512 * * * \\
(0.00)\end{array}$ & $\begin{array}{l}-1.121 * * * \\
(0.00)\end{array}$ & $\begin{array}{l}0.449 * * * \\
(0.00)\end{array}$ \\
\hline
\end{tabular}

\section{Instrumental variables}

$\begin{array}{ll}\text { Pension and retirement } & 0.123 * * * \\ \text { expenses per worker } & (0.00)\end{array}$

$0.142 * * *$

(0.00)

Industry wage
$0.253^{* * *}$
$0.142 * * *$
(0.00)

\begin{tabular}{lllllll}
\hline Observations & 5,093 & 5,093 & 6,006 & 6,006 & 3,765 & 3,765 \\
Adjusted R & 0.08 & 0.39 & 0.05 & 0.30 & 0.10 & 0.36 \\
$\begin{array}{l}\text { F-statistic } \\
\text { J-statistic }\end{array}$ & 46.17 & & 40.40 & & 20.08 & \\
(p-value) & & & & & & $(0.32)$ \\
\hline
\end{tabular}




\section{Table 8. Cash Holdings and Exogenous Welfare Index}

This table presents the regression results on the effect of the exogenous welfare index on cash holdings. All variables, apart from the exogenous welfare index, are defined in Table 2. Models 1 to 4 are similar to Model 2 from Table 4. In Models 1 to 3 we replace our original EWI with each component of the exogenous index. In Model 4 we replace EWI with the exogenous welfare index. Strength of discharge laws in Model 1 is constructed by summing up three distinct dummy variables for each of the three wrongful discharge law exceptions, each set equal to one if the firm is in a state that has adopted the exception, and zero otherwise. Strength of health \& safety laws is a dummy variable set equal to one if a firm is located in one of the 25 states and territories that have their own unique occupational safety and health programs, and zero otherwise. Strength of family laws is a dummy variable set equal to one if a firm is located in a state with strong family laws, and zero otherwise. The exogenous welfare index is constructed by summing up strength of discharge laws, strength of health \& safety laws, and strength of family laws, and ranges between 0 and 5 . All regressions include year dummies but we do not report their coefficient estimates. The p-values in parentheses are based on robust standard errors clustered at the firm level. *,**, and *** denote statistical significance at the $10 \%, 5 \%$, and $1 \%$ levels.

\begin{tabular}{|c|c|c|c|c|}
\hline Variables & (1) & (2) & (3) & (4) \\
\hline Strength of discharge laws & $\begin{array}{l}0.027 * * * \\
(0.00)\end{array}$ & & & \\
\hline Strength of health \& safety laws & & $\begin{array}{l}0.036 * * * \\
(0.00)\end{array}$ & & \\
\hline Strength of family leave laws & & & $\begin{array}{l}0.057 * * * \\
(0.00)\end{array}$ & \\
\hline Exogenous welfare index & & & & $\begin{array}{l}0.019 * * * \\
(0.00)\end{array}$ \\
\hline Cash flow & $\begin{array}{l}-0.194 * * * \\
(0.00)\end{array}$ & $\begin{array}{l}-0.200 * * * \\
(0.00)\end{array}$ & $\begin{array}{l}-0.196^{* * * *} \\
(0.00)\end{array}$ & $\begin{array}{l}-0.195 * * * \\
(0.00)\end{array}$ \\
\hline Net working capital & $\begin{array}{l}-0.412 * * * \\
(0.00)\end{array}$ & $\begin{array}{l}-0.408 * * * \\
(0.00)\end{array}$ & $\begin{array}{l}-0.404^{* * *} \\
(0.00)\end{array}$ & $\begin{array}{l}-0.403 * * * \\
(0.00)\end{array}$ \\
\hline Capital expenditure & $\begin{array}{l}-0.785 * * * \\
(0.00)\end{array}$ & $\begin{array}{l}-0.765 * * * \\
(0.00)\end{array}$ & $\begin{array}{l}-0.740 * * * \\
(0.00)\end{array}$ & $\begin{array}{l}-0.755^{* * *} \\
(0.00)\end{array}$ \\
\hline Leverage & $\begin{array}{l}-0.271 * * * \\
(0.00)\end{array}$ & $\begin{array}{l}-0.279 * * * \\
(0.00)\end{array}$ & $\begin{array}{l}-0.271^{* * *} \\
(0.00)\end{array}$ & $\begin{array}{l}-0.267 * * * \\
(0.00)\end{array}$ \\
\hline Acquisitions & $\begin{array}{l}-0.412 * * * \\
(0.00)\end{array}$ & $\begin{array}{l}-0.413 * * * \\
(0.00)\end{array}$ & $\begin{array}{l}-0.418^{* * * *} \\
(0.00)\end{array}$ & $\begin{array}{l}-0.411 * * * \\
(0.00)\end{array}$ \\
\hline Market-to-book & $\begin{array}{l}0.005 * * * \\
(0.00)\end{array}$ & $\begin{array}{l}0.005^{* * *} \\
(0.00)\end{array}$ & $\begin{array}{l}0.005 * * * \\
(0.00)\end{array}$ & $\begin{array}{l}0.005 * * * \\
(0.00)\end{array}$ \\
\hline Size & $\begin{array}{l}-0.035^{* * * *} \\
(0.00)\end{array}$ & $\begin{array}{l}-0.034 * * * \\
(0.00)\end{array}$ & $\begin{array}{l}-0.034 * * * \\
(0.00)\end{array}$ & $\begin{array}{l}-0.034 * * * \\
(0.00)\end{array}$ \\
\hline Ind. cash flow volatility & $\begin{array}{l}1.485 * * * \\
(0.00)\end{array}$ & $\begin{array}{l}1.576^{* * * *} \\
(0.00)\end{array}$ & $\begin{array}{l}1.542 * * * \\
(0.00)\end{array}$ & $\begin{array}{l}1.514 * * * \\
(0.00)\end{array}$ \\
\hline $\mathrm{R} \& \mathrm{D}$ expenditure & $\begin{array}{l}0.043 * * * \\
(0.00)\end{array}$ & $\begin{array}{l}0.044 * * * \\
(0.00)\end{array}$ & $\begin{array}{l}0.043 * * * \\
(0.00)\end{array}$ & $\begin{array}{l}0.043 * * * \\
(0.00)\end{array}$ \\
\hline Dividend dummy & $\begin{array}{l}-0.045^{* * * *} \\
(0.00)\end{array}$ & $\begin{array}{l}-0.048^{* * * *} \\
(0.00)\end{array}$ & $\begin{array}{l}-0.044 * * * \\
(0.00)\end{array}$ & $\begin{array}{l}-0.044 * * * \\
(0.00)\end{array}$ \\
\hline Intercept & $\begin{array}{l}0.471 * * * \\
(0.00)\end{array}$ & $\begin{array}{l}0.503 * * * \\
(0.00)\end{array}$ & $\begin{array}{l}0.498 * * * \\
(0.00)\end{array}$ & $\begin{array}{l}0.467 * * * \\
(0.00)\end{array}$ \\
\hline Year dummies & Yes & Yes & Yes & Yes \\
\hline Observations & 10,969 & 10,969 & 10,969 & 10,969 \\
\hline Adjusted $\mathrm{R}^{2}$ & 0.57 & 0.57 & 0.57 & 0.58 \\
\hline
\end{tabular}




\section{Table 9. Fortune's “100 Best Companies to Work For" Sample}

Panel A presents the regression results on the effect on cash holdings of inclusion in Fortune's list. All variables are defined as in Table 2. The Fortune dummy is equal to one if a firm appears in the list in the year in question. Models 1 and 2 present the results of panel regressions in which we regress cash holdings on a set of determinants and the Fortune dummy. All regressions include year dummies but we do not report their coefficient estimates. Model 3 tests for across-firm effects. Model 4 presents the results of a Fama-MacBeth regression. The p-values in parentheses are based on robust standard errors clustered at the firm level. *,**, and $* * *$ denote statistical significance at the $10 \%, 5 \%$, and $1 \%$ levels. In Panel B, we use propensity score matching to test for the difference in cash holdings between firms in Fortune's list and matched firms in Compustat using the nearest neighborhood and Gaussian kernel-matching techniques. We use all the control variables from Panel $\mathrm{A}$ in the matching process. Bootstrapped standard errors are based on 50 replications with replacement. Biascorrected $95 \%$ confidence intervals are reported in brackets and p-values in parentheses.

Panel A: Regression Results

\begin{tabular}{|c|c|c|c|c|}
\hline & \multicolumn{2}{|c|}{ OLS } & \multirow{2}{*}{$\begin{array}{c}\text { Across firm } \\
(3)\end{array}$} & \multirow{2}{*}{$\begin{array}{c}\begin{array}{c}\text { Fama } \\
\text { MacBeth }\end{array} \\
(4) \\
\end{array}$} \\
\hline Variables & (1) & (2) & & \\
\hline Fortune dummy & $\begin{array}{l}0.067 * * * \\
(0.00)\end{array}$ & $\begin{array}{l}0.043 * * * \\
(0.00)\end{array}$ & $\begin{array}{l}0.110 * * * \\
(0.05)\end{array}$ & $\begin{array}{l}0.059 * * * \\
(0.00)\end{array}$ \\
\hline Cash flow & $\begin{array}{l}-0.009 * * * \\
(0.00)\end{array}$ & $\begin{array}{l}-0.008^{* * * *} \\
(0.00)\end{array}$ & $\begin{array}{l}-0.013^{* * *} \\
(0.00)\end{array}$ & $\begin{array}{l}-0.012 * * * \\
(0.00)\end{array}$ \\
\hline Net working capital & $\begin{array}{l}-0.013 * * * \\
(0.00)\end{array}$ & $\begin{array}{l}-0.012 * * * \\
(0.00)\end{array}$ & $\begin{array}{l}-0.018^{* * *} \\
(0.00)\end{array}$ & $\begin{array}{l}-0.022 * * * \\
(0.01)\end{array}$ \\
\hline Capital expenditure & $\begin{array}{l}-0.420 * * * \\
(0.00)\end{array}$ & $\begin{array}{l}-0.336^{* * * *} \\
(0.00)\end{array}$ & $\begin{array}{l}-0.395^{* * *} \\
(0.00)\end{array}$ & $\begin{array}{l}-0.418^{* * *} \\
(0.00)\end{array}$ \\
\hline Leverage & $\begin{array}{l}-0.061 * * * \\
(0.00)\end{array}$ & $\begin{array}{l}-0.055^{* * *} \\
(0.00)\end{array}$ & $\begin{array}{l}-0.085^{* * *} \\
(0.00)\end{array}$ & $\begin{array}{l}-0.097 * * * \\
(0.00)\end{array}$ \\
\hline Acquisitions & $\begin{array}{l}-0.389 * * * \\
(0.00)\end{array}$ & $\begin{array}{l}-0.393^{* * *} \\
(0.00)\end{array}$ & $\begin{array}{l}-0.641^{* * *} \\
(0.00)\end{array}$ & $\begin{array}{l}-0.386^{* * * *} \\
(0.00)\end{array}$ \\
\hline Market-to-book & $\begin{array}{l}0.002 * * * \\
(0.00)\end{array}$ & $\begin{array}{l}0.002 * * * \\
(0.00)\end{array}$ & $\begin{array}{l}0.002 * * * \\
(0.00)\end{array}$ & $\begin{array}{l}0.002 * * * \\
(0.00)\end{array}$ \\
\hline Size & $\begin{array}{l}-0.016 * * * \\
(0.00)\end{array}$ & $\begin{array}{l}-0.012^{* * * *} \\
(0.00)\end{array}$ & $\begin{array}{l}-0.011 * * * \\
(0.00)\end{array}$ & $\begin{array}{l}-0.015^{* * *} \\
(0.00)\end{array}$ \\
\hline Ind. $\mathrm{CF}$ volatility & $\begin{array}{l}0.009 * * * \\
(0.00)\end{array}$ & $\begin{array}{l}0.001 * * * \\
(0.01)\end{array}$ & $\begin{array}{l}0.016^{* * * *} \\
(0.00)\end{array}$ & $\begin{array}{l}0.017 * * * \\
(0.00)\end{array}$ \\
\hline R\&D expenditure & $\begin{array}{l}0.025^{* * *} \\
(0.00)\end{array}$ & $\begin{array}{l}0.019 * * * \\
(0.00)\end{array}$ & $\begin{array}{l}0.044 * * * \\
(0.00)\end{array}$ & $\begin{array}{l}0.029 * * * \\
(0.00)\end{array}$ \\
\hline Dividend dummy & $\begin{array}{l}-0.066^{* * *} \\
(0.00)\end{array}$ & $\begin{array}{l}-0.044 * * * \\
(0.00)\end{array}$ & $\begin{array}{l}-0.092 * * * \\
(0.00)\end{array}$ & $\begin{array}{l}-0.065 * * * \\
(0.00)\end{array}$ \\
\hline Intercept & $\begin{array}{l}0.317 * * * \\
(0.00)\end{array}$ & $\begin{array}{l}0.320 * * * \\
(0.00)\end{array}$ & $\begin{array}{l}0.299 * * * \\
(0.00)\end{array}$ & $\begin{array}{l}0.315 * * * \\
(0.00)\end{array}$ \\
\hline \multirow{4}{*}{$\begin{array}{l}\text { Year dummies } \\
\text { Industry dummies } \\
\text { Observations } \\
\text { Adjusted } \mathrm{R}^{2} \\
\end{array}$} & Yes & Yes & No & No \\
\hline & No & Yes & No & No \\
\hline & 77,869 & 77,869 & 12,495 & 77,869 \\
\hline & 0.22 & 0.29 & 0.32 & 0.25 \\
\hline \multicolumn{5}{|c|}{ Panel B: Propensity Score Matching } \\
\hline & & $\begin{array}{r}\text { Neare } \\
\text { neighbor }\end{array}$ & od & $\begin{array}{c}\text { Gaussian } \\
\text { kernel }\end{array}$ \\
\hline \multicolumn{2}{|c|}{$\begin{array}{l}\text { Difference in cash holdings } \\
\text { between Fortune and matched } \\
\text { control firms }\end{array}$} & \multicolumn{2}{|c|}{$\begin{array}{c}0.029 \\
(0.00) \\
{[0.008,0.064]}\end{array}$} & $\begin{array}{c}0.013 \\
(0.00) \\
{[-0.003,0.033]}\end{array}$ \\
\hline
\end{tabular}




\section{Highlights:}

- We find that firms committed to employee well-being hold more cash.

- This relation is stronger when human capital is more important to the firm.

- Our results are consistent with the predictions of the stakeholder theory.

- Overall, we provide novel evidence on the role of labor in a firm's cash policy. 